\title{
Kur'ân'daki Kıssa ve Mucizelerin Aklen İzahının İmkânı Üzerine
}

\author{
Resul Ersöz ${ }^{\mathrm{a}}$
}

Özet

Kur'an'ın mucizevi yönlerinden biri olan hikâyeler, Allah'ın sözleriyle bize aktarılmış, geçmişte yaşamış ya da yaşanması muhtemel olan olaylardır. Allah Teâlâ bu kıssalar ile tüm zamanlardaki vahyin muhataplarına hem vahyin ve nübüvvetin ispatını ve hem de onların geçmişin tecrübelerinden ibret, ders ve öğüt almalarını hedeflemektedir. Şüphesiz ki Kur'ân kıssalarının vahyin ilk muhatapları nezdinde belirgin bir karşılığı/cevabı bulunmaktadır. Çağdaş insana düşen şey, aynı kıssalardan tüm zamanlara hitap edebilecek külli, ahlâkî ve felsefî manalar çıkarabilmektir. Kıssalar etrafında cereyan eden mucizeler ise literatüre şöyle geçmiştir: Mucizeler, peygamberlik iddiasında bulunan kimselerin elinde zuhur ettirilen ve insanların bir benzerini meydana getirmekten aciz kaldıkları olağanüstü hadiselerdir. Kur'ân'da yer alan kıssa ve mucizelerle ilgili önemli hususlardan biri, onların modern bilimlere ait sebep-sonuç, nedensellik, yalınlık, ölçülebilirlik, tarafsızlık ve tarihi kronolojiye uygunluk gibi ölçütlerle değerlendirilebilir olup olmadığ meselesidir. Makalemizin amacı, Kur'ân' da bulunan kıssa ve mucizelerin aklen ve yukarıda temas ettiğimiz ölçütler çerçevesinde izah edilmelerinin mümkün olabileceğine işaret etmektir. Bölece onlardan evrensel ilkeler çıkarılabilmesi mümkün olabilecektir.
Anahtar Kelimeler

Tefsir

Kur'ân Kıssaları

Mucize

Aklî İzah

Makale Hakkında

Geliş Tarihi: 10.02.2020

Kabul Tarihi: 01.09.2020

Doi: 10.18026/cbayarsos.687401

\section{On the Possibility of Intellectual Explanation of the Stories and Miracles in the Qur'an}

\section{Abstract}

The stories, which are one of the miraculous aspects of the Quran, are the events that have been conveyed to us by the word of Allah, lived in the past or are likely to be experienced. With these stories, Allah is aiming both the proof of the revelation and prophethood to the interlocutors of all revelations and to receive a warning, lessons and advice from the past experiences. Undoubtedly, the stories of the Quran have a clear response/answer on the floor of the first interlocutors of the revelation. The thing that falls to modern people is to be able to infer from general, moral and philosophical meanings that can appeal to all times from the same stories. The miracles that occur around the stories are conveyed to the literature as follows: Miracles are extraordinary events was created in the hands of those who claim to be prophets and the peoples are unable to create a similar one. One of the important issues related to the stories and miracles in the Qur'an is the question of whether they can be evaluated with criteria such as cause-effect, causality, simplicity, measurability, impartiality and compliance with historical chronology. The purpose of our article is to point out that the stories and miracles in the Quran can be evaluated within mentally and the framework of the criteria we have contacted above. So, It will be possible to create universal principles from them.
Keywords

Tafseer (Exegesis)

Stories of The Qur'an

Miracle

Intellectuel explanation

About Article

Received: 10.02.2020

Accepted: 01.09.2020

Doi: 10.18026/cbayarsos.687401 


\section{Giriş}

Kur'ân'da birtakım kıssalar bulunmaktadır ve bunlar onun i'câz yönlerinden birini oluşturmaktadır. Buna mukabil onun bütünüyle bir kıssalar kitabı olduğu söylenemez. Kur'ân kıssaları hakkındaki genel kabul, onların, -hayalî ya da gerçek- bildiğimiz hikâyeler kabilinden birer hikâye olmadığıdır. Yani kıssalar, gerçekleşmiş olayların Allah'ın kelamıyla tarafımıza aktarılmış halinden ibarettir. Bunun yanında, kıssaların, tarihî birer gerçeklik olmakla birlikte Kur'ân'ın bir tarih ve bilim değil, edebî bir eser olmasından hareketle onda dramatik (temsîlî) ve mitolojik (ustûrî) kissaların bulunduğu da savunulmuştur. (Halefullah, 2002: 187 vd.) Görünen o ki bu konu, rasyonalist zihinler için bu bağlamdaki tartışmaların merkezinde yer almaya devam edecektir. Allah Teâlâ söz konusu kıssalar ile vahyin tüm muhataplarına, hem vahyin ve nübüvvetin ispatını ve hem de geçmişin tecrübesinden ibret, ders ve öğüt almalarını hedeflemiştir. Yani amaç salt geçmişi hikâye etmek değil, onu "şimdiye" ve "geleceğe" hizmet ettirmektir.

Kur'ân kıssalarının Hz. Peygamber'e söyledikleri ile günümüz insanına söyledikleri arasında bazı farkların bulunabileceğini, hatta bunun bir gereklilik olduğunu asla göz ardı etmememiz gerekir. Bununla birlikte kıssaların, bir medeniyet projesi olan İslâm'ın; -tevhîd akidesi ekseninde- faziletli bir toplum oluşturma amacına katkı sağlaması hedeflenmiştir. Yoksa amaç tarihi bilgi aktarımı değildir. "Kur'ân neredeyse her zaman, kıssalara küllî, ahlâkî ve felsefî manalar vermeyi amaçlamıştır. Kur'ân kıssalarında kişi ve yer isimlerinden bahsedilmemiş olması kıssaları evrenselleştirmeye yöneliktir" der Muhammed İkbâl (1877-1938). (İkbâl, 2016: 116-117) Elmalılı Muhammed Hamdi Yazır (1878-1942) da kissaların mebde ve meâd (başlangıç ve son/sonuç) ile ilgili içerdiği esasların kapsamını şöyle ifade etmiştir. 'Öncekilere ait bütün hikâyeler, bütün eski eserler, öncekilerin bütün kitapları ve meydana gelmiş bütün hadiseler, içerdikleri tahrif ve hurafeler çıkarılarak okunsa bile insan hayatının başlangıcı ve sonu bakımından ifade edecekleri sabit hakikatler, Kur'ân'ın bu kıssalarda işaret ettiği esasların sınırını aşamaz.'(Yazır, 1968: 3: 2210)

Kur'ân kıssalarıyla ilgili önemli hususlardan biri, onların değerlendirilme meselesidir. Kıssaların modern bilimlere ait sebep-sonuç, nedensellik, yalınlık, ölçülebilirlik, tarafsızlık ve tarihi kronolojiye uygunluk gibi ölçütlerle değerlendirilebilir olup olmadığ değerlendirilebilir olmadığ 1 yönünü işaret etmektedir. Bu durum kanaatimizce kıssalar ad1na bir nakısa değildir. Çünkü amaç, yukarıda da ifade ettiğimiz gibi tarih yazmak ve tarihten haber vermek değildir. Amaç, tevhîd, insan davranışlarına yön vermek, fitrata dikkat çekmek, ahlakı gerçekleştirmek ve yeryüzünde bir halife olarak ahlaka ve adalete dayalı sosyal bir düzen kurmasında insana katkı sağlamaktır.

Buna mukabil, genel eğilimin, kıssaların bilimsel ölçütlerle değerlendirilemeyeceği yönünde olması, kanaatimizce, "Kur'ân kıssalarının bilimsel hiçbir değeri ve açılaması yoktur" anlamına gelmemektedir. Nitekim bazı kıssalarda söz konusu edilen olağanüstü hadiseler, bir kısım müfessir tarafından modern bilimlere uygun olarak sebep-sonuç ve illiyet prensibi çerçevesinde açıklanmıştır.

Söz buraya gelmişken, kıssaları detaylı bir şekilde açılamak adına bazı müfessirlerin çokça müracaat ettikleri İsrâiliyât konusuna da değinmek gerekir. Bu hususta İbn Teymiye (728/1328) ve akabinde talebesi İbn Kesîr (774/1373) tarafından bu tür rivayetlere mesafeli olmak gibi bir usûl geliştirilmiştir. (İbn Teymiye, 2004: 13: 366) İbn Teymiye, Abdullah b. 
Mes'ûd (32/652-53) ile Abdullah b. Abbas'ın (68/687-88) bazı durumlarda Ehl-i Kitaptan nakillerde bulunduğunu söyler. Ona göre Rasûlullah "Bir âyet bile olsa benim adıma tebliğ ediniz. Ayrıca İsrâil oğullarından rivayette bulunabilirsiniz, bunda bir mahzur yoktur. Kim kasten benim adıma yalan söylerse (hadis uydurursa) cehennemdeki yerini hazırlasın" (Buhari, Enbiya: 50; Tirmizî, İlim: 13; İbn Mâce, Mukaddime: 5; Ahmed b. Hanbel, 3: 39, 46) buyurarak Ehl-i kitaptan rivayette bulunmaya izin vermiştir. Bununla birlikte İsrâiliyât, kıssaların istişhad1/takviyesi amacıyla kullanılabilinse de, itikada ve ahkâma müteallik konularda kullanılmaz. İbn Teymiye'ye göre isrâiliyât üç kısımdır. Bunlardan ilki, elimizde sıhhatine dair delil bulunan, bu sebeple sahihliği bildiğimiz haberler. Diğeri, elimizdeki bilgilerin aleyhine olduğu ve bu sebeple yalan olduğunu bildiğimiz haberler. Üçüncüsü de, Ne sahih ve ne de yalan; ne doğrulayabildiğimiz ve ne de yalanlayabildiğimiz, hakkında sükût edilen haberler." Bunlardan ilkinin -sahih olduğundan dolayı- kullanılması caizdir. İkincisi yalan haber olduğundan kullanılması caiz değildir. Üçüncüsünün kullanılması caiz olmakla birlikte dini bir faydası yoktur. Ashâb-1 Kehf'in ayrıntılarında olduğu gibi. (İbn Teymiye, 2004: 13: 366367) İbn Kesîr'e göre "İsrâil oğullarından rivayette bulunabilirsiniz, bunda bir mahzur yoktur" sözü ile Rasûlullah, aklın caiz görerek onaylayıp kabulüne hükmettiği haberleri kastetmiştir. Aklın muhal görüp batıl olduğuna hükmettiği ve zannı galiple yalan olduğuna kani olduğu haberler ise -Allahu a'lem- yukarıdaki hadiste söz konusu edilen cevaz kapsamının dişındadır. Yani bu tür haberleri rivayet etmek de dinî alanda kullanmak da caiz değildir. (İbn Kesîr, 1985: 7: 372)

Söz konusu usûl, modern çağda, 'bu bağlamdaki rivayetlerde akla, mantığa ve hayatın gerçeklerine aykırı olmamak ile bid'at ve hurafe içermemek' (Ersöz, 2018: 187) gibi şartlar taşıması şeklinde daha da somut hale getirilmiştir. İsrâiliyât konusunda, "akla, mantığa ve hayatın gerçeklerine aykırı olmamak ile bid'at ve hurafe içermemek" üzerine vurgu yapılması İsrâiliyâtın tamamen reddedilmediğinin de bir kanıtıdır. Söz konusu vurgu ayrıca, kıssaları ya olduğu gibi kabulü ya da sünnetullah dairesinde açıklamayı gerekli kılmaktadır. Bu açıdan kanaatimizce kıssalardaki bazı olağanüstülükleri sünnetullah ve sebep-sonuç ilişkisi dâhilinde açıklama gayretinde olan müfessirleri -bunu bir ictihâd mesabesinde kabul ederekyadırgamamak gerekir.

Ayrıca çalışmamız, bazı Kur'ân kıssalarının, hem yukarıda söz konusu ettiğimiz faydaları temin ve hem de tüm olayları pozitivizm bağlamında; sebep-sonuç ve nedensellik prensibi ekseninde değerlendiren modern insana -anladığ 1 dilden hitap ederek- cevap verebilmek adına aklen izahının mümkün olabileceğinin de gösterilmesini hedeflemektedir.

\section{Kissa ve Mucize Kavramları}

\subsection{Kıssa Kavramı: Sözlük ve Terim Anlamı}

Kıssa sözlükte; "izini sürmek, adım adım takip etmek, birine bir konuyu haber vermek/bildirmek ve bir şeyi makasla kesmek" anlamlarında "القصن/kss" kökünden türetilmiş, çoğulu "kısas" olan; Kur'ân' da "kasas" şeklinde aynı anlamda kullanılan "hikâye, haber ve olay" anlamında bir isimdir (Râgib el-İsfahânî, 404; İbn Manzûr, 7: 73-74).

"Birbirini takip eden bir konu hakkında bütün merhale ve detaylarıyla bilgi vermek" (İbn Useymin, 2001: 50) manasından hareketle kıssanın terim anlamını şöyle ifade etmek mümkündür. İnsanların ibret alması ve hidayete ulaşmasına yönelik olarak Kur'ân-ı Kerim'de 
geçen, geçmiş peygamberler, kavimleri ve diğer geçmiş toplumlara ait -genellikle zaman ve mekândan soyutlanmış- hikâyelere/olaylara kıssa denir (Demir, 69). Ancak Kur'ân kıssaları (Kısasu'l-Kur'ân) denince, bundan hikâye manası anlaşılmaz. Çünkü kıssa ile hikâye birbirinden farklıdır. Kıssalarda anlatılanlar doğru ve gerçek olaylardır. Hikâyede ise, böyle bir şart aranmaz. Doğru da olabilir, hayal mahsulü de. (Çetin, 2012: 266) Muhammed Halefullah'a (1916-1997) göre Kur'ân kissaları tamamen edebî kıssalar olup, onlarda söz konusu edilen olayların gerçekte yaşanmış olaylar olup olmadığı müfessirlerce göz ardı edilmiştir. Bu yüzden kıssalar, müfessirlerin te'vile ve edebî metoda başvurmadan çözemedikleri birçok problemin kaynağı olmuştur. (Halefullah, 2002: 188) Halefullah kıssaları tarihsel (edebî), dramatik (temsîlî) ve mitolojik (ustûrî) olmak üzere üçe ayırmıştır. Tarihsel kıssalar, 'rasyonel gerçekliği ve tarihî anlatımı olmayan', (Halefullah, 2002: 168) okuyucu ve dinleyicilerin duygularına hitap eden edebiyatçıların hikâye ile ifade ettikleri tanım kapsamındadır. Dramatik kıssalar sanatsal karakteriyle tarihî kıssalardan daha etkili olmakla birlikte gerçeğe de hayale (varsayım) de dayanabilir. Zemahşerî (538/1144), Nisâbûrî (730/1329?) ve Ebû Hayyân (745/1344), bu görüştedir. Bu tür kıssaların yalanlığına da doğruluğuna da hükmedilemez. (Halefullah, 2002: 188, 192) Halefullah, dramatik (temsilî) kıssaların tümünün kurgu olduğunu iddia etmez. Ona göre iki melek kıssası ve bu kıssada Dâvûd (as) başından geçenler gerçektir. Kur'ân'da Allah'ın kurguya başvurması maksadına ulaşması adına Allah'ın buna muhtaç olmasından değil, insanoğlunun kurguya muhtaç olmasındandır. Bu, Kur'ân'ın başvurduğu insan psikolojisine uygun bir üsluptur. (Halefullah, 2002: 193) Mitolojik (ustûrî) kıssalar ise, ilk iki kıssa türünden farklı olarak bazı mitolojilerin dinî amaçlarla kıssa formuna döndürülmesinden ibarettir. Bu tür kıssaların Kur'ân'da bulunmasının hiçbir mahzuru yoktur. Fahreddîn er-Râzî (606/1210) Nahl Sûresi 16: 64. Âyet bağlamındaki açılamalarıyla Kur'ân'da mitolojinin bulunmasını caiz görmektedir. (Halefullah, 2002: 216-217) Kur'ân kıssaları, dinî birtakım gayeleri gerçekleştirmek için vaz' edilmiştir. Bunlar, Allah'ın vahdaniyeti, vahiy ve Peygamberliğin ispatı, dinlerin esasta bir olduğu, zalim ve yoldan çıkmışları uyarma, müjdeleme, Kurdet-i İlâhiyenin tecelli ettiği yerler, hayır, şer, sabır, sızlanma, ceza, şükür, nankörlük ve benzeri bütün Kur'ânî gayelerdir. (Kutub, 1969: 221)

Kur'ân kıssalarını konu ve gaye bakımından üçe taksim etmek mümkündür. Bunlardan ilki, peygamberlerin dine davetini, kavminin buna karşı duruşunu, inanan ve inanmayanların akıbetini ve bu bağlamda bazı harikaları kapsayan kıssalardır. İkincisi, geçmiş hadîseler ve ölüm korkusuyla yurtlarından çıkan kimseler (el-Bakara 2: 243), Tâlut, Câlut, Âdemoğulları, Ashâb-1 Kehf, Zülkarneyn, Kârun, Ashâb-1 Sebt, Meryem, Ashâb-1 Uhdûd ve Ashâb-1 Fîl gibi şahıslarla ilgili Kur'ân kıssalarıdır. Üçüncüsü de Âl-i İmrân Sûresi'nde söz konusu edilen Bedir ve Uhut, Tevbe Sûresi'nde söz konusu edilen Huneyn ve Tebuk ile Ahzâb Sûresi'nde söz konusu edilen Hendek harpleriyle, Hicret ve İsrâ gibi Rasûlullah zamanında meydana gelen hadîselerle ilgili kıssalardır (Ersöz, 2019: 100-101).

\subsection{Mucize Kavramı}

\subsubsection{Mucizenin Sözlük ve Terim Anlamı}

Mucize (المعزة)), aciz kalmak, bir şeye güç ve kudret yetirememek anlamına gelen (Râgıb elİsfahânî, 404; el-Fîrûzâbâdî, 1966: 1: 65; es-Sefarînî, 1982: 2: 289; İ. Mustafa- A. H. ez-Ziyât H. Abdülkâdir - M. A. en-Neccâr, 1989: 2: 585) "a-ce-ze" (عزj) kökünden türetilmiş, "if'âl (إعجال) (إعاز) olan bir ism-i faildir. Sözlük manası, "meydan okuma 
anında hasmı aciz bırakan/acze düşüren" (Doğan, 1996: 785); "hasmın bir benzerini yapmaktan aciz bırakıldığı şey" ve "amel, görüş ve tedbir gibi işlere güç yetirememek" (elFîrûzâbâdî, 1966: 1: 65) demektir.

Terim olarak mucize; hasımlarına/muhataplarına meydan okuma ve nübüvvetini doğrulama amaciyla Allah tarafından Peygamberlik iddiasında bulunan zatın elinde zuhur eden/ettirilen, insanların bir benzerini meydana getirmekten aciz kaldıkları, âdet (tabiat kanunları) ve sünnetullaha aykırı harikulade olay demektir (Abdülkâhir el-Bağdâdî, 296; esSefarînî, 1982: 2: 289; Hasan Ziyâüddîn Itr, 1994: 19-20; Ersöz, 2019: 115). İbn Hacer elAskalânî'ye (852/1449) göre; yanında meydana geldiği kimseleri itiraz etmekten aciz bıraktığından dolayı "mucize" (معزة) ismi kullanılmıştır. Kelimenin sonundaki ta-i merbûta (o) mübalağa içindir. (İbn Hacer el-Askalânî, 6: 581-582) Klasik kelamcılar tarafından yapılan bu tarif, çoğunlukla doğruluğu/sahihliği sabit olmayan rivâyetlere dayanmaktadır ve aynıla günümüze taşınmıştır. Örneğin Hz. Peygamber'e nisbet edilen harikulâde birçok hadise, Hz. Peygamber'in otuz erkek gücünde olduğuna yahut dokuz eşi bulunduğuna aynı gece bütün eşlerini dolaştığına (el-Buhârî, Gusl: 12, Nikâh: 103) dair rivayetlerde olduğu gibinaklinde bir sorun olmasa bile, ilk ravilerin sübjektif değerlendirmelerine dayanmaktadır. Zira mucizelerle ilgili rivayetlerin büyük bir bölümü, doğrudan Hz. Peygamber'in ağzından nakletmek suretiyle değil, üçüncü kişilerin gözlem ya da anlatımlarına dayanmaktadır. (Demircan, 2015: 194-195) Bundan sebep, sübjektif değerlendirmelere dayanan rivayetler üzerine hüküm inşa etmenin isabetli bir tutum olmadığ 1 kanaatindeyiz.

Söz konusu tariften de anlaşılacağı üzere bir hadisenin mucize diye isimlendirilebilmesi için birtakım şartları taşıması gerekir. Öncelikle fiil, Peygamber'e değil, Allah'a aittir. Fiilin nübüvvet iddiasıyla birlikte nübüvvetin ispatı kabilinden bir peygamber elinde zuhur etmesi gerekir. Bir benzerinin insanlar tarafından (eliyle) yapılamaması ve bu hususta meydan okuması. Âdetullaha/sünnetullaha aykırı bir olay olması (en azından öyle algılanması). Bu şartların birlikte bulunduğu hadiseler gelenekte mucize kavramıyla karşılanmıştır. Ancak Kur'ân'da yer almayan bu kavramın, literatüre ve Müslümanların gündemine, Kur'ân'ın inzalinden birkaç asır sonra (ikinci ve üçüncü asırlarda) girdiğini söylemek mümkündür. Söz konusu kavram, makalemizde, klasik tanımıyla değil, ancak ‘Peygamberleri desteklemek amacıyla onlara verilen olağanüstü hadiseler' anlamında ele alınacaktır.

Mucizeler, terim anlamına esas olmak üzere birtakım tasniflere tabi tutulmuştur. Kanaatimizce bunlardan en isabetlisi, onların "hissi/kevnî" haberî ve "aklî" şeklinde üçe ayrıldığ1 tasniftir. Hissî/kevnî mucizeler "Hz. Musa'nın aşasının ejderhaya dönüşmesi; çölde kayadan on iki pınar fışkırtması, Hz. İsâ'nın çamurdan kuşa can vermesi vb." daha çok duygulara hitap eden maddî harikalardır. Haberî mucizeler de Peygamberlerin vahye dayalı verdikleri gaybî haberlerdir. Aklî mucizeler ise Kur'ân'ın vahiy mahsulü olduğu ile Hz. Peygamberin nübüvvetinin akla uygunluğuna dair tefekkür (düşünme) ve teakkule (akletme) davet eden manevi harikalardır. Buna göre nübüvvet ve Kur'ân, birbirini tamamlayan aklî bir mucizedir. Hz. Musa, Hz. İsa ve diğer peygamberlere atfedilen hissî/kevnî mucizeler ise rivayetleri, sıhhatleri ve delâletleri bakımından sorunludur. (Reşid Rızâ, 1947: 9: 155) 


\subsubsection{Kur'an'da Mucize}

Kur'ân-1 Kerim'de mucize kelimesi geçmemektedir. "a-ce-ze" kökünden toplam yirmi bir âyette, “aciz mi kaldım (أعجزتُ)"[el-Maide, 5/31], “aciz birakanlar (معزين)"[el-En'âm, 6/134], “Allah'ın âyetlerini yalanlama konusunda yarışanlar (معاجزين)" [el-Hac, 22/51], ve "Allah'1 aciz bırakmak (ليُجْزَه)" [el-Fâtır, 35/44] gibi -fiil, mastar, ism-i fail ve sıfat olarak- birtakım kullanımlara rastlansa da, bunların yukarıda söz konusu ettiğimiz ıstılah ile bir ilgisi yoktur. Ayrıca, Kur'ân'da mucizeye karşılık gelen müstakil herhangi bir kelime de bulunmamaktadır. Hadislerde de mucize kelimesine rastlanmaz. Hadislerde kullanılan acz kökünden türemiş çeşitli kelimeler, sözlük anlamında kullanılmıştır.

Bazı âyetlerde geçen ve işaret, açık alâmet, delil ve belge anlamina gelen "âyet (أية)" kelimesi, 'Allah'ın varlığına, birliğine güç ve kudreti ile yaratıcılığına delalet eden deliller' anlamına gelmektedir. Bu bağlamda, "İnsanlara ufuklarda ve kendi nefislerinde âyetlerimizi (birliğimizin ve kudretimizin alâmetlerini) göstereceğiz ki onun (Kuran'ın) gerçek olduğu, onlara iyice belli olsun. Rabbinin her şeye şahit olması, yetmez mi?" (Fussılet 41: 53) âyetini Vehbe Zuhaylî şöyle tefsir etmiştir: O kâfirlere, Kur'ân'daki âyetlerimizin doğruluğunu, Allah katından geldiğini; kudretimizin ve vahdaniyetimizin delillerini göklerde, yerde ve onların güneş, ay, yıldızlar, gece, gündüz, rüzgârlar, yağmurlar, ağaçlar, dağlar, denizler vb. müştemilatı ile kendi yaratılışlarındaki mükemmellik ve ince hikmeti göstereceğiz. Bunu, Kur'ân'ın Allah tarafından gönderilen hak bir kitap olduğunu açıklamak adına yapacağız. (Vehbe ez-Zuhaylî, 483) Buna mukabil aynı kelime (âyet), zamanla hâriku'l-âde/âdet dışı hadiselere (mucizelere) de teşmil edilmiştir. Müşriklerin mucize taleplerinin söz konusu edildiği âyetlerde de "âyet/âyetler (أية/الأيات)" (el-Ankebût, 29: 50-51; el-İsrâ, 17: 90-93) kelimesinin geçmiş olmas1, kelimenin muhtemel anlamlarından birinin de hâriku'l-âde/âdet dışı olay olduğuna delalet eder. Bu durumda âdet dışı dediğimiz olay/olayların, hakikaten sünnetullah dışında bir olaya mı tekabül ettiği, yoksa muhatap kitlenin bunu anlayabilecek bir kapasiteye sahip olmamasından $\mathrm{m}$ bu şekilde isimlendirildiği konusu üzerinde yoğunlaşmak gerekir. İkinci ihtimalin doğru olması durumunda hâriku'l-âde olayların âdet dışılı̆̆ının mutlak değil, muvakkat/geçici bir durum olduğu, zamanla aklen izahının mümkün olduğu yani bunların da âdet/sünnetullah bağlamında gerçekleştiği sonucuna varılır. Kanaatimizce daha isabetli olan bu ikinci ihtimaldir. Diğer taraftan, "âyet" kelimesinin manasının mucizeyle sinırlandırılmamasına, dolayısıyla anlamının daraltılmamasına dikkat edilmesi gerekir. Mucize konusundaki diğer değerlendirmeler makalemizin devamında “Kur'ân Kıssaları ve Mucizeler Etrafında Yapılan Tartışmalar" başlı̆̆ı altında yapılacaktır.

\section{Kur'ân Kıssaları ve Mucizeler Etrafında Yapılan Tartışmalar}

Kur'ân kıssaları etrafında yaşanan tartışmaların, onların bilimsel (sünnetullah, sebep-sonuç ilişkisi ve nedensellik bağlamında) açıklamasının olup olmamasından çok, menşei ve gerçekliği hakkında yaşandığı söylenebilir. Diğer taraftan, Kur'ân kıssaları üzerinde yapılan tartışmaların, aslında, menşei ve kaynağı bağlamında Kur'an'ın geneli hakkındaki tartışmalardan bağımsız bir konu olmadığını da ifade etmemiz gerekir. Oryantalistler tarafından ileri sürülen ve sürekli gündemde tutulmaya çalışılan konu, Hz. Muhammed'in (sav) bir peygamber olmadığı, dolayısıyla Kur'ân'ın da Allah tarafından gönderilmiş bir kitap olmayıp bizatihi Muhammed tarafından Ehl-i kitap ve Uzak Doğu dinlerinden ilham alınarak uydurulmuş bir kitap olduğu' fikri ve ön kabulüne dayanmaktadır. Theodore Bibliander, Herbelot de 
Mollainvile, Ludovico Marraccio, George Sale, Abraham Geiger, Edward Henri Palmer, Reinhart Pieter Dozy, Gustav Weil, Aloys Sprenger James William Hampson Stobart, Sir William Muir, Josef Horovitz, Julius Wellhausen, Ignaz Goldziher, William St. Clair Tisdall, Theodor Nöldeke, Hartwig Hirschfeld, Leone Ceatani, Heinrich Speyer, William Montgomery Watt, Christoph Luxemberg, Claude Gillot, İbn Warraq vb. oryantalistlerin bu husustaki görüşlerine dair ayrıntılı bilgi için bakınız: (Yaşar, 2017: 29-96).

Müslümanların Kur'ân'ın kaynağı konusundaki görüşleri ise tamamen, Kur'ân'ın “Onun bir vahiy ürünü olduğu (Âl-i İmrân, 3: 44; en-Nisâ, 4: 163); önceki kitapları tasdik etmenin (elBakara 2: 97; Âl-i İmrân 3: 3; el-Mâide 5: 46) yanında insanları hidayet etmek amacıyla (elBakara 2: 2, 185; Yunus 10: 57; el-İsrâ 17: 9; Lokman 31: 4) gönderildiği" öngörüsü ekseninde tezahür etmektedir. Hz. Muhammed (sav) de vahiy yoluyla Allah'tan aldığı Kur'ân'ı insanlara tebliğ etmek; ondaki emir ve yasakların uygulamasını yaparak örneklik oluşturmak üzere gönderilmiştir.

Kur'ân hakkındaki oryantalist telakki, aslında iki temel kabule dayanmaktadır. Bunlardan ilki, Mekke toplumunun Yahudilik ve Hristiyanlık hakkında bilgi sahibi olduğudur. Diğeri de 'Hz. Muhammed'in söz konusu iki dine ait bilgileri Ehl-i Kitap'tan (komşuluk ilişkileri ve ticaret sebebiyle Hristiyanlarla ilişki kurup Hristiyan olan (Varaka b. Nevfel (610) vb.) kişilerden aldığı ve bir takım ekleme ve çıkarmalar yaparak bunları kendine göre uyarlayıp peygamberliğini ilan ettiğidir. İslâm'ın tamamen reddine/inkârına dayanan bu yaklaşım, müsteşrik Rudi Paret'in satırlarına şöyle yansımıştır:

“O (Muhammed), yıllarca süren uğraşıları sonucunda Mekkelilerin yalnızca küçük bir bölümünden hüsn-i kabul görürken, çoğunluğundan ise sadece alay ve aşağ1lanma hasat etmiş, amansız bir mukavemetle karşı karşıya kalmıştı. Bu durumda, aradığı teselliyi, daha önce de Allah elçilerinin sadece bir azınlık katında hüsn-i kabul gördüğünü, ama kavimlerinin büyük çoğunluğunun kendilerine gönderilen kurtuluş çağrısına kulak asmadıkları için ilâhî bir cezaya kurban gittiklerini haber veren Kitâb-1 Mukaddes kıssalarında ve diğer hikâyelerde buldu. Peygamber zaman içerisinde bir düzine hikâye -bunları Josef Horovitz' in ifadesiyle kısaca "helak kıssaları olarak niteleyebiliriz- öğrendi ve bunları tebliğine dâhil etti. Nuh ve tufan, Lût ve (hiçbir yerde adıyla anılmayan) Sodom-Gomore'nin helaki ve nihayet Musa, (inanan azınlık olarak) İsrâiloğulları, Firavun, (inkârcı büyük çoğunluk olarak) Mısırlılar ve denizden geçerken helâk edilmeleri hakkındaki hikâyelerin tamamı Kitâb-1 Mukaddes kaynaklıdır. Bunlara, kadim Arap efsanelerinden alınan, aynı şekilde müthiş felaketlerle helak olan toplulukları anlatan hikâyeleri de katılmıştır. Bunlar; Âd kavmi ile mesajını reddettikleri Allah'ın elçisi Hûd, Semûd kavmi ile Peygamberleri Salih ve son olarak da Medyenliler ile peygamberleri Şuayb'ın kıssasıdır. Muhammed, kavminin ekseriyeti tarafından ciddi bir hayal kırıklığına uğratıldığı zaman, kelimenin tam anlamıyla kendini bu hikâyelerle özdeşleştirmiş ve gün geçtikçe kendi yaşadıklarını aynıyla bu hikâyelerde bulmaya başlamıştır. (Paret, 2018: 135)

Montgomery Watt'a (1909-2006) göre, Hz. Peygamber'in ortalama Mekkelilerden daha fazla bilgi sahibi olan kişilerle Kitâb-1 Mukaddes hakkında konuşmuş olması muhtemeldir. Ancak onun bu tür kimselerden elde ettiği Yahudilik ve Hristiyanlık hakkındaki bilgisi sınırlıdır. 
(Öztürk, 2016: 80; W. M. Watt'an naklen 1988: 44-45) Kanaatimizce Montgomery Watt'in bu değerlendirmesi, bizim 'Hz. Peygamber' in kıssalar etrafında Yahudi, Hristiyan ve diğer topluluklar hakkında sahip olduğu bilgilerin çoğunlukla vahiy kaynaklı olduğu' yönündeki anlayışımızı destekler mahiyettedir.

Müsteşrikler tarafından, kıssalar üzerinden Kur'ân hakkında ileri sürülen 'kaynağının Kitâb1 Mukaddes ve Uzak Doğu dinleri olduğu' şeklindeki iddialar, nihayetinde, imana taalluk eden konular üzerinde yoğunlaşmaktadır ve bunların ispat edilip kendilerinin bu konuda ikna edilmesine imkân yoktur. Zira imana taalluk eden mevzular, kanitlanmaya veya ispatlanmaya konu olan mevzular değildir. Üstelik Tevrat ve İncil'de ele alınan kıssaların Kur'ân'da da söz konusu edilmesi onun adına bir nakısa değildir. Zira Kur'ân açıkça Tevrat ve İncil'i tasdik etmek üzere geldiğini ifade etmektedir (Âl-i İmran 3: 50; Yusuf 12: 37, 111).

Fahreddîn er-Râzî, Kur'ân'ın ilk muhataplarından olan müşriklerin kıssalar bağlamında Rasûlullah'a herhangi bir eleştiri yöneltememelerini, Rasûlullah'ın peygamberliğinin ispatı ile kıssaların Kur'ân' daki varlığının yerindeliğinin bir delili olarak görmektedir.

“Rasûlullah ümmî bir adam idi. Bir şeyler öğrenmek amacıyla başka bir memlekete gitmedi. Üstelik Mekke bir ulemâ memleketi değildi ve onda herhangi bir ilim kitabı da bulunmuyordu. Sonra o Kur'ân'1 getirdi. Bu Kur'ân öncekilerin kıssalarını ihtiva etmekteydi ve kavmi de kendisine son derece düşman idiler. Şayet söz konusu kıssalar Tevrat ve İncil'le örtüşmeseydi “sen bu kıssaları olması gerektiği gibi doğru getirmedin" demek suretiyle onu tenkit eder, bu konuda onu suçlarlardı. Onu suçlamaya şiddetle istek duymasına rağmen (müşriklerden) hiç kimsenin böyle bir şey söyleyemediğinden, onun bu kıssaları, -Tevrat ve İncil'den ya da herhangi bir kimseden öğrenmeksizin- Tevrat ve İncil'le örtüşecek şekilde getirdiğini anlarız. İşte bu, Rasûlullah'ın söz konusu kıssaları, Allah Teâlâ tarafından vahiy yoluyla alıp haber verdiğine delalet etmektedir" (Fahreddîn er-Râzî, 2013: 18: 76-77).

Kur'ân'ın yaklaşık yirmi üç yılda tedricen inmesi ve bu manada Ashâbın neredeyse birçok âyetin inişine şahitlik etmeleri onun, Hz. Peygamber'in talebi üzerine değil, Allah'ın isteği üzerine indiğine delâlet eder. Dolayısıyla Kur'ân'a Hz. Peygamber'in bir müdahalesinden söz edilemez. Kur'ân'a göre o, vahyin arifesinde, -diğer Hanifler gibi- ağır bir yükün altında kaygılı, şaşkın ve sıkıntı içinde inler durumdadır (el-İnşirah 94: 1-3). M. Abdullah Draz (1894-1958) din konusunda saf aklın yeterli olmayacağından; yanlışları tespit etmeye kadir olsa da yerine konulacak şeyi tespit etmede yetersiz kalacağından hareketle Hz. Peygamber'in akliyla vahiy üretemeyeceğini söyler.

“O halde Muhammed (as.), Allah'ın sayısız sıfatlarını, müşahede ve gayb âlemiyle olan münasebetlerini, ölümden sonra insana layık gördüğü akıbeti ve buna benzer bildirdiği bütün hakikatleri; bunların hiçbirinden rücu etmeden ve aynı zamanda Kitap Ehli'nin elinde bulunan Kitâb-ı Mukaddes'le olan şaşırtıcı benzerliklerine hiç halel getirmeden hangi 1şıkla keşfetmiştir? Vahiyle yönetilmeyen saf bir aklın, böyle bir yolda, bu kadar emin ve basiretli bir şekilde yürüyemeyeceği aşikârdır. Nitekim Kur'ân, ilk vahyi aldığı sırada Hz. Muhammed'in Kitab'ın ve imanın ne olduğunu bilmediğini bildirerek bizi bu hususta teyid eder. (eş-Şûrâ 42: 52) ayrıca o, ahlakî, ictimâî ve dinî özellik arz eden teşrîi eserlerden de habersizdi. Allah'a nasıl 
ibadet edilmelidir? Fert için; cemiyet ve insanlık için en iyi hareket kaidesi ne olmalıdır? O, bütün bu hususlarda en ufak bir malumata bile sahip değildi. Dini yönden kendisi nasıl hareket edeceğini bile bilmezken nasıl olur da başkalarını hidayete sevk edebilirdi? (ed-Duhâ 93: 7)." (Draz, 2016: 125-126) “O halde vahiy, Hz. Peygamber için hiçbir şahsi dahli olmaksızın yaşadığı bir tecrübedir: vahiy, onun tamamen pasif bir şekilde maruz kaldığı, geldiği zaman kendisinden kaçamadığı ve ihtiyacı olduğu zaman da kendisini ona hazırlayamadığı bir hadisedir" (Draz, 2016: 144).

Hz. Peygamber, "(Ey Muhammed! Onlara) "Muhakkak ben de sizin gibi bir insanım. Ancak bana ilâhınızın bir tek ilah olduğu vahyediliyor." de." (el-Kehf 18: 110) âyetinde de işaret edildiği üzere vahiy almasının dışında her yönüyle diğer insanlardan farksızdır. Gaybı da bilmez (elEn'âm 6: 50; Hud 11: 31). Örneğin ifk hadisesinde zanniyla hareket etmemiş neredeyse bir aydan fazla konunun aydınlanması için vahiy beklemiştir. (Çağırıcı - Karaman - Dönmez Gümüş, 2006: 4: 58-61; Fayda, 2000: 508) Bütün bunlar onun vahiyle beslendiğine ve Kur'ân'a yönelik bir müdahalesinin olmadığına delâlet eder.

“Nitekim Kur'ân getirdiği sistemin Hz. Peygamber de dâhil olmak üzere bütün Araplar için yepyeni bir sistem olduğunu açıkça vurgular. Geçmiş milletlerin tarihlerinden bölümler zikrederken peygamber olmadan evvel Hz. Muhammed'in de kavmi gibi bu tarihe aşina olmadığını çok defa tekit etmekten geri kalmaz" (Draz, 2016: 124). "Her nâzil olan âyet, ona, yeni ve önceden bilinmeyen malumat getirmiştir. Bu, tıpkı, vahiy dalgalarının durduğu yerde ışıkları sönen bir lamba gibidir. Bu ışığın ötesinde Hz. Peygamber diğer insanlardan farksızdır. O, geçmiş ve gelecekle ilgili, sağlam insan zekâsının nüfuz edemediği her hususta mütevazı ve dürüst bir şekilde soru işareti koymuştur" (Draz, 2016: 144).

Diğer taraftan Kur'ân'da Hz. Peygamber'e ait şahsi iz düşüm arayanlar hayal kırıklığına uğrar. İddia edildiği gibi Kur'ân Hz. Peygamber tarafından imal edilmiş olsaydı, Kur'ân'da onun dilini ve duygularını fark etmemek mümkün olmazdı. Birçok âyette ona yöneltilen sitem ve eleştiriler (et-Tevbe 9: 43; işin bir diğer yönüdür. "Allah seni affetti. Fakat doğru söyleyenler sana iyice belli olup, sen yalancuları bilinceye kadar onlara niçin izin verdin?" (et-Tevbe 9: 43) ve "Ĕ̆ger seni sebatkâr kılmasaydık, gerçekten, nerdeyse onlara birazcık meyledecektin. O zaman, hiç şüphesiz sana hayatın ve ölümün sıkıntılarını kat kat tattırırdık; sonra bize karşı kendin için bir yardımcı da bulamazdın." (el-İsrâ 17: 74-75) gibi âyetler Hz. Peygamber'in yanılabileceğine ve dahası her dediğinin vahiy olmadığına delâlet eder. "Sunulan idealden en ufak bir uzaklaşmadan ötürü Kur'ân-1 Kerîm'in Hz. Peygamber'e şiddetli sitemlerde bulunması nadir değildir" (Draz, 2016: 146). Nitekim Enfâl Sûresi 8: 67-68; Tevbe Sûresi 9: 43, 113: Mü'minûn Sûresi 23: 37 ve Abese Sûresi 80: 1-10 âyetler buna delâlet etmektedir.

Diğer taraftan Hz. Peygamber'in birçok konuda kendiliğinden karar vermediğine, aksine vahiy beklediğine şahit olmaktayız. Bunlardan biri de kıble meselesidir. Hz. Peygamber başlangıçta Kudüs'ü kıble edinmiş olmasına rağmen hep içinde Kâbe'yi arzulamıştır. Bu hususta kararı kendisi vermemiş Allah'ın emrini beklemiştir. Nihayet Bakara Sûresi 139-144. âyetler nazil olmuş ve böylece kıble değişmiştir. 
İbn Âşûr (1879-1973), Kur'ân ile Kitâb-1 Mukaddes'in tevhîd inancı vb. birçok konuda örtüştüğünü, buna mukabil bazı fikhî konularda maslahat ve tarihi şartlar gereği birtakım farkl1lıkların meydana geldiğini söyler. İbn Âşûr Kur'ân'ın Kitâb-1 Mukaddesi tasdikini “Elinizde bulunan (Tevrat ve Incil'i) tasdik etmek üzere indirdiğim (Kur'ân'a) iman edin. Onu inkâr edenlerin ilki olmayın. Âyetlerimi az bir menfaat ile değiştirmeyin ve yalnızca benden sakınıp korkun." [elBakara, 2/41] âyeti bağlamında şöyle açıklamıştır:

“Kur'ân'ın yanlarında bulunanı (Tevrat ve İncil) tasdik etmesi ile Kur'ân'ın, onların peygamberlerinin; tevhîd, faziletleri emretmek, rezillikleri yasaklamak, adaleti tesis etmek, va'd-vaîd, öğütler ve kıssalar gibi davet ettiği hidayeti içeriyor olması kast edilmektedir. Bu konularda bir benzeşme söz konusudur ve durum ortadadır. İhtilaf edilen konular ise maslahat ve tarihi şartlar gereği değişmesi gereken bazı (fıkhî) konulardır. Zira kutsal kitapların tümünün aslı (kaynağı) birdir. Bu sebeple, (fıkhî konularda gerçekleşen) bu ihtilaf/değişiklik "nesh" diye isimlendirilmiştir. Çünkü nesh, sabit bir hükmü gidermek/kaldırmak demektir. Bu iş, "iptal etmek" yahut "yalanlamak" diye isimlendirilmemiştir. Yani nesh, maslahatların temini ve mefsedetlerin defi gereği hükümlerde değişiklik yapmak demektir." (İbn Âşûr, 1984: 1: 459)

Diğer taraftan, Hz. Peygamber'in (bize göre vahye dayalı) kıssa bilgisiyle aynı konuda Tevrat'ta anlatılanların bir kısmının birbirine benzemesinden, onun kıssaları Tevrat ve diğer kaynaklardan kopya ettiği sonucunu çıkarmak hiç de isabetli görünmemektedir. Kur'an zaten kendinin Tevrat'ı tasdik ettiğini söyler. Kur'ân'ın “Tevrat ve İncil'i tasdik etmek üzere gönderildiğini" açıklamasının amacı, onun kaynağının vahiy olduğu ile Hz. Muhammed'in bir peygamber olduğu konusunda müşrikleri Kitâb-1 Mukaddes'in (Abdullah b. Selam (43/663-64) gibi bazı kişilerin) desteğiyle ikna etmektir. el-Ahkâf Sûresi 46/8-12. âyetler bu konudan bahsetmektedir. (Öztürk, 2016: 85) Tam tersine Kur'ân'ın Kitâb-1 Mukaddes'te geçen peygamber kıssalarını ve önceki milletlerin hayat hikâyelerini mesaj ve öğüt verme ekseninde alıntılaması, ortaya koyduğu doktrinin içerik bakımından önceki dinlere benzerlik arz etmesi elbette doğal ve hatta zorunludur. Burada tuhaf ve yanlış karşılanması gereken şey, aslında İslâm dininin önceki dinlere benzerlik arz etmemesidir. Benzeşme ya da bazı konularda örtüşme dediğimiz şey, İslâm ile önceki dinlerin kaynağının tek olduğuna delalet eder. Keza birçok peygamber Mezopotamya ve Arabistan'a gelmiş ve nazil olan tüm kitaplar ilk etapta Sâmi dilleri ile yazılmıştır. Bu durum, söz konusu dinlerin, niçin ortak dil, tarih, kültür ve kavramları kullandıklarını açıklamaktadır. (Yaşar, 2017: 97-98)

Maide Sûresi 5/48. âyette geçen "müheymin" kelimesi de "denetleyen/şahitlik eden" (ezZemahşerî, 2015: 1: 627; es-Sâvî, 4: 193) manasıyla "musaddik" kelimesine yakın ve hatta onu destekleyici bir mana ifade etmektedir. Dolayısıyla her iki kavram birlikte değerlendirildiğinde Kur'ân'ın açıkça kendini evvelki kitapları tasdik edici, denetleyici ve şahitlik edici olarak nitelediği görülür. Bu da müsteşriklerin Kur'ân'a kaynak arama çaba ve iddialarını boşa çıkarmaktadır. (Öztürk, 2016: 91)

Genelde Kur'ân'ın, özelde kıssaların Kitab-ı Mukaddes ile benzeşmesinin mutlak olmadığını da burada ifade etmemiz gerekir. Çünkü aralarında kapsam, amaç, metot ve üslup bakımından birçok fark bulunduğunu fark etmemek mümkün değildir. Öncelikle ifade etmeliyiz ki Kur'ân, teferruata girmez, çarpıcı bir üslupla konunun ders ve ibret alınması gereken yönle- 
rini anlatır. Kitab-1 Mukaddes ise muhatabını işin teferruatında boğan bir tarih kitabı gibidir. Tevrat, adeta İsrâiloğulları'nın hayatını anlatırken, İncil(ler), Hz. İsâ'nın (as) hayatını anlatmaktadır. Kur'ân kıssalarında vurgu, tevhîd ve ahlak iken, bu kıssaların Tevrat ve İncil sürümünde, böyle bir amaç ve vurgu söz konusu değildir. Üstelik Tevrat'ta, -Kur'ân'ın cevap vermek zorunda kaldığı (el-Bakara 2: 102)- Allah ve bazı peygamberlere yönelik yakışıksız isnat ve ithamlarla karşılaşılmaktadır. Örneğin Allah'ın Nuh tufanından sonra pişman olduğu iddia edilmiştir. (Kitâb-ı Mukaddes, 1997: Tekvin 9: 11-17) Hz. Süleyman yedi yüz eş ve üç yüz cariye edinmek, katil, şirk ve küfür ile itham edilmiştir. (Kitâb-ı Mukaddes, 1997: I. Krallar, 2: 13-25 ve 11: 2-13) Diğer taraftan, kıssalar bağlamında Tevrat ve İncil'de bölgesellik ve hususilik, Kur'ân'da ise evrensellik ve genellik en karakteristik vasıftır. Muhammed İkbal'e (1877-1938) göre Kur'ân'ın kıssaları yeni fikirlerle canlandırmak ve böylece ilerleyen zamanın ruhuna uydurmak için onları tamamen ya da kısmen dönüştürme metodu, önemli bir husustur. Kur'ân'ın bu kıssalarla ilgilenmekteki maksadı nadiren tarihle ilgilidir. Kur'ân neredeyse her zaman kıssalara küllî, ahlâkî ve felsefî bir anlam vermeyi amaçlar. Kişi ve yer isimlerinin atlanması bu amaçladır. (İkbâl, 2016: 115-116.) Netice olarak diyebiliriz ki Kur'ân, tarih felsefesinin, tarihe egemen olan kanunların çıkarılabileceği genel prensip ve esasları ihtiva eden yegâne ilâhî kitaptır (Yaşar, 2017: 165-166) ve dolayısıyla böyle bir kitaba, Kitab-1 Mukaddes' in kaynaklık ettiğini iddia etmek akla zarar bir husustur.

Kıssalar bağlamında ele alacağımız diğer bir konu da mucizeler meselesidir. Başta tarifi olmak üzere Müslümanlar arasında mucizeler konusunda bir takım görüş ayrılıkları görülmektedir. İbarenin aynıyla Kur'ân'da geçmemiş olması muhtemelen bu hususta yaşanan görüş ayrılıklarının en önemli sebeplerinden biridir. "Âyet" kelimesi birebir mucize manasına gelmemekle birlikte belli bir dönemden sonra israrla "mucize" manasına hamledilmiştir. Buna göre "âyet", Allah'ın sabit kanunlarının yine Allah tarafından geçici bir süre devre dışı bırakılması yani değişmesi (hâriku'l-âde/âdet dışı) anlamına gelmektedir. Hâlbuki Hz. Peygamber döneminde bu kelimeye (âyet) böyle bir mana (mucize manası) verilmemiştir. Nitekim âyet, Kur'ân ve hadislerde; “Allah'ın varlığına ve birliğine delâlet eden delil (el-Bakara 2: 164; el-En'âm 6: 95-99; Yunus 10: 5, 67; er-Ra'd 13: 2-4; en-Nahl 16: 66-69; el-Enbiya 21: 31-32; er-Rûm 30: 20-25; Buhârî, "Bed'ü'l-Halk": 88); peygamberlerin sıdkını ispat eden delil (elMü'minûn 23: 50); kıyâmet alametleri (el-En'âm 6: 158; Müslim, "Fiten": 39-41); peygamberlerin Allah tarafından görevlendirilmiş birer elçi olduklarını ispat eden hâriku'l-âde olaylar (Âli İmran, 3/49; el-Maide, 5/114; el-A'râf, 7/73; el-İsrâ, 17/59; Meryem, 19/17-21; Tâhâ, 20/22) ve Kur'ân'ın tamamı veya belli bölümleri" gibi manalarda kullanılmıştır. Dolayısıyla Kur'ân ve hadislerde peygamberleri tasdik amacıyla onlar eliyle meydana getirilen bazı hâriku'l-âde olayların âdet/sünnetullah dişı hadiseler olduğu hiçbir zaman ifade edilmemiştir. Yani Kur'an-1 Kerim bize klasik tanımıyla "mucize" diye kabul edilmesi gereken herhangi bir olay veya olgu dayatmamaktadır. (Zeyveli, 2015: 126) Çünkü söz konusu olay ve olguları ele alan âyetlerin mucize kavramıla karşılanan istılaha delâletleri kat'i değildir. Âyete, âdet/sünnetullah dışı olaylar anlamında mucize manası verilmesi daha sonraki zamanlara tekabül etmektedir.(Yavuz- Çetin, 1991: 4: 243)

Mucizeler konusunda göz önünde tutulması gereken diğer bir husus, Hz. Peygamber'in (sav) müşriklerin anladığı manada bir takım hissî/kevnî âyetle desteklenmediğidir. Nitekim bu gerçek "Bizi, (Kureyş'in istediği) mucizeleri göndermekten, alıkoyan şey, ancak öncekilerin onları yalanlamış olmasıdır. (Nitekim) Semûd kavmine o dişi deveyi açık bir mucize olarak verdik de onlar bu 
yüzden (söz dinlemeyip) zalim oldular. Oysa biz mucizeleri sırf korkutmak için göndeririz." (el-İsrâ, 17: 59) âyetinde açıkça ifade edilmiştir. Bu âyetten, önceki peygamberlere, -müşriklerin anladığı manada mucize kabilinden- bir takım harikalar verilmiş olsa bile -ki bunlar, kanaatimizce tabiatüstü hadiseler değildir- bu tür harikalarm Hz. Peygamber'e verilmediği/verilmeyeceğini çıkarmak mümkündür. Diğer taraftan, İslâmî kaynaklarda ayın ikiye ayrılmasından (şakku'l-kamer) başka, -müşriklerin Hz. Peygamber'e (sav) meydan okuması üzerine gerçekleştirilen- hissi/kevnî bir mucizeden söz edilmemiştir. (Buhârî, "Menâkıb": 27; "Tefsir (Kamer)", 1; "Menâkıbu'l-Ensâr", 36; Müslim, "Sıfatu'l-Münâfikîn", 43, 45, 48; Tirmizî, "Tefsir (Kamer)": 3-4; “Fiten": 20) Kur'ân'da da bu hadisenin mucize olduğuna dair açık bir işâret bulunmamaktadır. Hatta şakku'l-kamer hadisesinin -bir meydan okuma olmadan- meydana geldiğine dair rivayetler bulunmaktadır. (el-Kurtubî, 2006: 20: 74; İbn Kesîr, 7: 449; Çağırıcı - Karaman - Dönmez - Gümüş, 2006: 5: 179-184) Bu da Müslümanlar arasında, Hz. Peygamber'e hissî/kevnî mucize verilmediğine dair bir kanaat oluşmasına yol açmıştır. (Demircan, 2015: 205) Buradan çıkan sonuç, en basitinden onun ümmetinin mucize kabilinden bir takım harikalarla imtihan edilmeyeceğidir.

Muhammed Abduh'un (1849-1905) mucizeler hakkındaki değerlendirmesi şöyledir:

“Mucizeler aklen caizdir. Yani, bunlar, iki zıttın bir araya gelmesi ve zıtlıkta zirve yapmak değildir. Mucizelerin, Peygamberlerden biri eliyle ve ancak Allah'ın kudretiyle meydana gelmesine bir mani yoktur. Mucizelere zahirleriyle iman etmemiz vaciptir. Ancak onlara olan bu imanımız, yaratılmışlarla ilgili Allah'ın (cc.) sünnetleriyle yol bulmamıza ya da bunların değişmeyeceği ve dönüşmeyeceği şeklindeki itikadımıza engel değildir. Nitekim Allah Teâlâ, kendisiyle vahyin sona erdiği Kitab'ında, peygamberlerin sonuncusu olan Hz. Peygamberin diliyle böyle buyurmuştur. Kur'ân ile birlikte artık mucizeler devri sona ermiştir. Zira artık insanlar rüştüne ermiş ve İslâm'a girmiştir. Bundan böyle harikaların şaşırtıcılığ1nın/cazibesinin iman ile ve fikir, ahlâk ve amel konusunda itidalden uzaklaşmak gibi fıtratı gösteren şeyleri güçlendirmekle bir alakası/bağlantısı kalmamıştır. Yani iş, çocukluk çağında olduğu gibi değildir. Aksine Allah Teâlâ insanı, vahyi ve imanı elde etmede son vahiy (Kur'ân) ile aklını kullanmaya yöneltmiştir. Sonra ona, edebe varana kadar açıklanmış, yorumlanmış ve şahitlendirilip ispatlanmış olarak vahyin bütün yol göstericiliğini lütfetmiştir. Akılları, delilleri anlamaya kifayet etmeyen kavimlerinin kalplerini cezbetmeye yönelik olan mucize kabili şeylerden Allah Teâlâ'nın kendileriyle peygamberleri teyit ettiği şeylere inanmamız, dinimizin akıl ve fıtrat dini olması ile onun, gözün şahitlik ettiği şeylere inanmamızı emretmiş olması çelişmez/aykırı düşmez. Çünkü Allah'ın yaratılmışlar hakkındaki kanununda/sünnetinde değişim ve dönüşüm olmaz/olamaz. (Reşid Rızâ, 1947: 1: 314-315)

Aynı konuda Reşid Rızâ'nın (1865-1935) görüşü de şudur:

“Akla aykırı olanın vukuu muhaldir (mucizelerin vukuu aklen muhaldir). Bir peygamberin aklen imkânsız/muhal olan bir şeyle teyit edilmesi mümkün değildir. Çünkü aklen imkânsız/muhal olan bir şey, vukuu da imkânsız olan demektir. Vuku bulan (meydana gelen) bir şey de imkânsız/muhal olamaz. Bundan dolayı kelamcilar mucizeleri "خوارق العادات/tabiat kanunlarına aykırı olan hadiseler" diye isimlendirmişlerdir. Kelamcılardan bazıları şunu söylemektedir: "Bu tür olayların, Allah'ın bilinmesini sadece peygamberlere tahsis ettiği ve ancak insanlara bildirmediği bir takım gizli ve ruhî sebepleri vardır." Meşhur ve yaygın olan gö- 
rüş/söylem ise şöyledir: "Allah onları sebepsiz yaratmıştır. Bunun sebebi, ilâhî sünnet ve kanunların, kendilerini vaz' edip yaratan Allah'a hükmetmediğini; aksine Allah'ın onlara hükmedip haklarında tasarrufta bulunduğunu göstermektir." Meşhur ve yaygın olan tanım budur ve bu açıkça ortadadır. Aksi takdirde, gayb âlemi hakkında (gayptan haber alarak) bu mutlak zıtlığı ispat etmeye kim güç yetirebilir ki? (Reşid Rızâ, 1947: 1: 315)

Günümüzde mucizeler konusundaki en önemli meselenin, mucize - sünnetullah ilişkisi olduğunu düşünüyoruz. Bu hususta Müslümanların kafasının da oldukça karışık olduğu görülmektedir. Zira her ne kadar sünnetullahın değişmezliği kanaati Kur'ân'dan da mülhem olarak, (el-İsrâ 17: 76-77). Müslümanlar arasında hâkim bir anlayış olsa da mucizeler sünnetullaha dâhil edilmemekte, sünnetullahın dışında birer hadise olarak kabul görmektedir. Bu, normal olmayan bir durumdur. Kanaatimizce, mucize kavramı çerçevesinde ifade edilen hadiseler de sünnetullah/âdetullah kapsamında cereyan etmektedir. Söz sünnetullah kavramına gelmişken o, İsrâ Sûresi 17/76 ve 77. âyetlerde ifade edildiği üzere bağlam bakımından, her ne kadar 'peygamberlerin çağrısına kulak asmayan ve mucizelerin de iş görmediği toplumların uğratıldığı' helâk ile karşılansa da onun sadece bu manaya hamledilmesinin doğru olmadığını ifade etmemiz gerekir. Çünkü bu, onun, -birçok açmaza sebep olacak şekildeanlam bakımından dondurulup sabitleştirilmesi demektir. Hatta bundan, tabiat kanunlarının yaratıcısının Allah olmadığı gibi bir sonuç çıkarmak bile mümkün olabilir.

Burada bir parantez açarak kısaca sünnetullah kavramı üzerinde de durmamız gerekir. Bu kavram, sünnet ve Allah (tamlanan ve tamlayan) kelimelerinden meydana gelen "Allah'ın sünneti" anlamında bir isim tamlamasıdır. Sünnet, çoğulu "sünen" olan " wiَنَنَ/سَنَّilinden türemiş; doğru yol, tutulan/takip edilen yol, âdet vb. anlamlarına gelen bir kelimedir. Marife

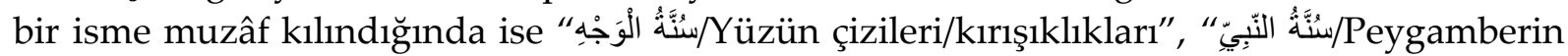

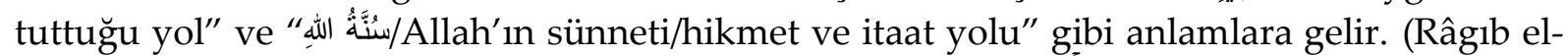

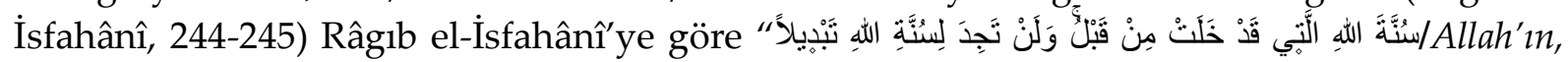
öteden beri süregelen kanunu budur. Allah'ın kanununda asla bir değişiklik bulamazsın." (el-Feth,

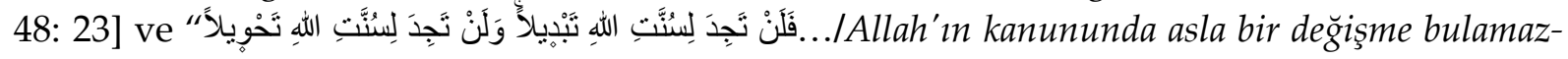
sin, Allah'ın kanununda kesinlikle bir sapma da bulamazsin." (Fâtır, 35: 43) âyetlerinde -her ne kadar suretleri farklı olsa da- şeriatların füruunda kastedilen gayelerde herhangi bir değişim ve dönüşüm olmadığına dair bir tenbih/uyarı vardır. O gaye de Allah Teâlâ'nın sevabına/rızasına ve himayesine ulaşmaya yönelik nefsi temizlemek ve eğitmektir. (Râgıb elİsfahânî, 245)

Kur'ân'da beş âyette sekiz kez geçen kelime, risâlete karşı çıkanlara ve zalimlere yönelik ilâhî cezalandırma/helâk (el-Ahzâb, 33: 38; Fâtır 35: 43; Ğâfir/Mü'min 40: 85), nihayetinde inananların muzaffer olacağına dair Allah'ın öteden beri süre gelen yasası (el-Feth 48: 23), bir kavme verdiğinin o kavim kendisini bozmadıkça değiştirmeyeceğine dair yasası (er-Ra'd 13: 11) ve göğün her katmanının yapması gereken görevler/yasalar (Fussılet 41: 12) gibi manalara gelmektedir. Buna göre sünnetullahın, 'kulların te' dib edilmesi/yola getirilmesi (Fâtır 35: 43), salâhı (er-Ra'd 13: 11) ve Allah'ın kâinâta yerleştirdiği eşyaya müteallik kanunları (Fussılet 41: 12)' şeklinde üç manaya geldiğini söylemek mümkündür. (Bağçeci, 2000: 7: 257) Binaenaleyh, sünnetullah kavramı her ne kadar bazı çağdaş araştırmacılar tarafından, 'Allah'ın varlıklarla ilgili olarak, izniyle öteden beri süregelen ve sürmeye devan edecek olan, kendine özgü 
değişmeyen bir davranış biçimidir’ (Ömer Özsoy, 2017: 43) şeklinde tarif edilip, “doğuştan insanlık için belirlenmiş sosyal kanunlar" anlamında yorumlandıysa da, Fussılet Sûresi 41: 12. âyet delâletiyle -bu anlamla birlikte-, "Allah'ın kâinata yerleştirdiği kanunlar/tabiat kanunları (âdetullah)" anlamina da gelmektedir.

Kur'ân'da sünnetullah olarak ifade edilen Nuh tufanı, Âd, Semûd, Hz. İbrahim'in kavmi, Ashab-ı Ress, Lût, Medyen, Ashab-ı Eyke, Sebe, Tubba', Firavun vb. kavimlerinin helâkine (cezalandırılmasına) dair olaylar -peygamberlerin bir dahli olmaksızın- tabiat kanunları çerçevesinde cereyan etmiştir. Bunlar da âyetin Kur'ân'da ifadesini bulan iki anlamından biri olan; Allah'ın varlığına, birliğine, güç ve kudreti ile yaratıcılığına delalet eden deliller manasında, Allah'ın birer âyetidir ve peygemberlerin peygamberliğini ispata dönük bir yönleri yoktur. Dolayısıyla bu hadiselerin muhatap kitlenin gözü önünde cereyan eden mucizelerle bir alakası bulunmamaktadır.

Diğer taraftan Reşid Rızâ ve Elmalılı Muhammed Hamdi Yazır gibi son devir İslâm âlimleri Allah'ın âyetlerini fiilî ve kavlî olmak üzere iki kısma ayırmıştır. Fiilî âyetler Allah'ın kâinata yerleştirdiği yasalara; bir anlamda sünnetullaha; kavlî âyetler de son vahiy Kur'ân'a tekâbül etmektedir.(Yavuz-Çetin, 1991: 4: 243) Genelde tüm insanlar, özelde müminler, kavlî âyetlere muhatap oldukları nisbette, fiilî âyetlere de muhataptırlar. İnsanın "في الأرض خليفةyeryüzünde halife" (el-Bakara 2: 30) olmasını, onun "fiilî âyetlerin bir muhatabı olarak yeryüzünü imar etmekle mükellef olması' şeklinde açıllamak mümkündür.

Kısaca, Kur'ân, -bazı müsteşriklerin iddia ettiği gibi- bizzat Kur'ânî ifadeyle; Kitabın da imanın da ne olduğunu bilmeyen, tıpkı kavmi gibi dinler hakkında herhangi bir aşinalığı ve kesin bir bilgisi bulunmayan, günün birinde peygamber olacağına dair bir fikir ve ümit taş1mayan ve bunun da ötesinde kendisi bile doğru yolu nasıl bulacağını bilmeyen bir kimsenin -Allah'tan vahiy almaksızın- üretebileceği bir kitap değildir.

\section{Mucizelerin Bilimsel ve Aklî İzahının İmkânı}

Kur'ân kıssalarıyla ilgili en önemli meselelerden birinin, kıssalarda yer alan ve çoğu peygamberlere ait harikaları/hissî mucizelerin modern bilimlere ait yöntemlerle, yani, sebepsonuç, nedensellik, yalınlık, ölçülebilirlik, tarafsızlık ve tarihi kronolojiye uygunluk gibi ölçütlerle değerlendirilmesi meselesi olduğunu ifade etmemiz gerekir. Konu tartışmalı ve bu sebeple netameli bir konu olmakla ve -daha önce de ifade ettiğimiz gibi- ibrenin değerlendirilebilir olmadığı yönünü işaret etmesine rağmen, Kur'ân ve sahih sünnette buna yönelik bir yasaklamanın bulunmamasından hareketle söz konusu harikaların sünnetullah ve sebepsonuç ilişkisi dâhilinde bilimsel birer açıklamasının da bulunabileceği kanaatindeyiz. Nitekim bazı tarihsel (edebî) kıssalarda söz konusu edilen harikalar, bir kısım müfessir tarafından, sebep-sonuç ve nedensellik prensipleri çerçevesinde açıklanmaya çalışılmıştır. Kur'ân, "Insanlarm bizzat kendi elleriyle yaptıklarn yüzünden karada ve denizde düzen bozuldu (yeryüzü yaşanmaz hale geldi). Nihayet Allah da belki vazgeçerler diye yaptıklarının bir kısmını onlara tattırır." (er-Rûm, 30: 41) âyetinde ve daha birçok âyette (el-Mâide 5: 65-66; el-A'râf 7: 96; Fâtır 35: 45; Nûh 71: 10-12; el-Cin 72: 16-17), sebebe ve nedenselliğe vurgu yaparken bunu görmezden gelmemiz mümkün olmamalıdır.

Mucizeler hakkındaki kelâmî öngörü/kabul, 'onların, nübüvvet iddiasında bulunan kişileri desteklemek amacıyla onlar eliyle gerçekleşen ve benzerinin hiçbir şekilde diğer insanlar eliyle gerçekleştirilmesinin mümkün olmadığı, fâilinin Allah (cc) olduğu olağanüstülükler' 
(en-Nesefî, 2007: 115-116) şeklindedir. Tariften de anlaşıldığı üzere mucizeler, nübüvveti ispat kabilinden, onlara şahit olan insanlar bakımından geçerli, zamanlı ve geçici hadiselerdir. Bu tür olağanüstülüklerin, onlara şahit olmayan insanlar katında bir bilgi ve haber niteliği taşımasından başka karşılığ yoktur. Nitekim müşriklerin 1srarla mucize talep etmelerine olumsuz bir cevap ve cevabın gerekçesi niteliği taşıyan "Bizim Peygamberi mucizelerle göndermemize mani olan şey, ancak o mucizeleri öncekilerin yalanlamış olmasıdır..." (el-İsrâ 17: 59) âyeti hissi/kevnî mucizeler devrinin çoktan kapandığının açık bir delilidir. Bu ve aşağıdaki âyetler, Hz. Peygamber'e hissî mucize verilmediğine ve verilmeyeceğine delâlet etmesiyle birlikte, zaten Arap kültüründe mucizelerle ilgili geçmişten tevarüs eden bir takım bilgilerin bulunduğuna delâlet eder.

Onlar: "Bizim için yerden bir kaynak fışkırtmadıkça sana asla inanmayacağız." dediler. "Veya senin bir hurma bahçen ve üzüm bağın olmall; öyle ki, içlerinden gürül gürül ırmaklar akıtmalısın." "Yahut iddia ettiğin gibi, üzerimize gökten parçalar yağdırmalısın veya Allah'ı ve melekleri gözümüzün önüne getirmelisin." "Yahut da altından bir evin olmalı, ya da göğe çıkmalısın." (Dahası) Bize okuyacağımız bir kitap indirmediğin sürece (göğe) çıktı̆̆ına da asla inanmayız." De ki: "Fesubhânallah (Ben bunu yapamam)! Ben, sadece beşer bir elçiyim (tanrı değilim).(el-İsrâ 17: 90-93) İnkârcılar: "Ona Rabbinden (bir takım) mucizeler indirilmeli değil miydi?" derler. De ki: Mucizeler göndermek ancak Allah'ın bileceği bir iştir. Ben ise sadece apaçık bir uyarıcıyım. Kendilerine okunmakta olan Kitab'ı/Kur'ân'ı (bir mucize olarak) sana indirmemiz onlara yetmemiş midir? Şüphesiz iman eden bir kavim için onda elbette rahmet ve ibret vardır.(el-Ankebût 19: 50-51)

İbn Rüşd'e (520/1126) göre mucizeler, insan aklını, kendisini idrak etmekten aciz bırakan ilahi olaylardır. Fazilete ulaşmadan onları anlamaya yol yoktur. Bir kimsenin fazilete erişmeden anlaşılması fazileti gerektiren ilkeleri araştırmaya girişmemesi gerekir. Ona göre asânın ejderhaya dönüşmesi hadisesinde olduğu gibi Kur'ân'ın mucizeliği işitme suretiyle gerçekleşmemiş, his ve insanların kabulü ile sabit olmuştur. (İbn Rüşd, 1964: 774-775) Görüldüğü gibi İbn Rüşd, Kur'ân'ın dışındaki mucizeleri kabul etmekte, buna karşılık Hz. Peygamber' in en açık mucizesinin Kur'ân-1 Kerim olduğu görüşünü savunmaktadır. Diğger mucizeler ise onunla aynı seviyede ve güçte değildir. İbn Rüşd'ün bu husustaki görüşlerinin aynı zamanda İslâm filozoflarının görüşlerini de yansıttığı kanaatindeyiz.

Muhammed Abduh, Kitâb-1 Mukaddes'te yer alan kıssa ve mucizeler bağlamında, modern insanın kâinat ve mahlûkâtın yaratılışını algılama problemini şöyle değerlendirmiştir:

“Tevrat ve İncil’in kâinât ve mahlûkâtın yaratılışı ile ilgili açılamaları, araştırmacıların (tabiat ilimleriyle meşgul olan âlimlerin) Hristiyanlığı reddine sebep olmuştur. Çünkü tecrübe (deneme) ve müşahedeye dayalı ilim, Tevrat'taki tarihi bilgilerin tersini söylemektedir. Zira eski insanlara ait elde edilen eser, işaret ve bulgular, -Tevrat'ın insanlık tarihiyle ilgili verdiği bilgilerin aksine- insanlık tarihinin, yeryüzünde çok daha eskilere uzandığını göstermektedir. Hal böyle olunca Ehl-i Kitab'ın bir kısmı bu durumu rasgele te'vîl etmiş, diğer bir kısmı da kutsal kitaplarını ve vahyi inkâr etmiştir." (Abduh, 1993: 4: 143; Reşid Rizâ, 1947: 1: 279-280)

Abdülaziz Câvîş'e (1876-1929) göre Allah Teâlâ bu dîni (İslâm'1), insan fitratına tezat oluşturmayan ya da onun itirazına imkân vermeyen mucizelerin dışındakilerle desteklemek- 
ten kaçınmıştır. Allah'ın (cc.) mucizesi, bizzat Kur'ân'ın kendisidir. Ankebût Sûresi 29/51. âyet, buna delalet etmektedir. (Câvîş, 1968: 147-148)

Reşid Rıâ, mucizeler konusunda akılcı ve modernist bir yaklaşım sergilemiştir. Onun genelde mucizeler, özelde Hz. Peygamber' in mucizeleri bağlamında aşağıdaki ifadeleri tefsirde ictimâî yönelişin mucize telakkisini de ortaya koyması bakımından önemlidir.

“Batılı düşünürlerin, Hristiyan kiliselerinin ve mezheplerinin itikâdî temelini oluşturan acâiplikler/mucizeler meselesiyle $\mathrm{Hz}$ Peygamber'in (sav) mucizelerini reddetmeleri konusunda diyebiliriz ki, Hz. Peygamber'in mucizeleri, bu asirda İslâm'ın lehine değil aleyhine, ulema ve fikir insanlarını ikna edici değil, engelleyici bir delil olmuştur. Şâyet Kur'ân, Hz. Mûsâ ve Hz. İsa'yı teyit eden mucizeleri hikâye etmeseydi, özgür düşünce sahipleri daha çok İslâm'a yönelir, daha yaygın ve hızlı bir şekilde hidâyete ererdi. Çünkü İslâm, akıl, ilim ve insan fıtratına uygunluk, fertlerin nefislerini (maddi-manevi) arındırmak ve kamu menfaatlerini temin etmek gibi esaslar üzerine bina edilmiştir. Allah (cc.) tarafından gönderildiğine dair Hz. Peygamber'in mucizesi, Kur'ân ve onun ümmî oluşudur. Bu, akıl, his ve vicdanla idrak edilebilen ilmî bir mucizedir. Kevnî mucizelere gelince bunlar, rivâyetinde, sıhhatinde ve delâletinde tevilleri çok, su götürür şüpheli işaretlerdir. Üstelik bunlara benzeyen harikuladelikler her zaman birçok insan tarafından izhar edilmektedir. Nitekim bu konuda Hint Müslüman sûfîlere isnat edilen rivâyetler, menkıbe cinsinden Tevrat ve İncil'de geçenlere oranla daha çoktur ve nihayetinde bunlar bu asırda ulemanın dinden (İslâm) nefret etmelerine yol açmaktadır."(Reşid Rızâ, 1947: 11: 155; Fahd b. Abdurrahman, 1983: 2: 557)

Hülasa, Allah Teâlâ, müşrikleri inzâr için kıssa ve mucizelerin desteğine başvurmuş, ancak bu, "(Müşriklerin gidişatı) tıpkı Firavun ailesi ve onlardan öncekilerin gidişatı gibidir. (Onlar da) Allah'ın âyetlerini inkâr etmişlerdi de Allah onları günahları sebebiyle yakalamıştı. Allah güçlüdür. O'nun cezası şiddetlidir." (el-Enfâl 8: 52) ve "Rabbimiz! Bizim payımızı hesap gününden önce ver" dediler." (Sâd 38: 16) vb. âyetlerde ifade edildiği üzere, müşrikler tarafından tepki ile karş1lanmış ve dolayısıyla bu yöntem kendilerinde olumlu bir makes bulmamıştır.

Kıssalarda söz konusu edilen mucizelerin tabiatı hakkında iki değerlendirme söz konusudur. Bunlardan ilki, 'onların olağanüstü olaylar' olduğu; diğeri de 'olağan hadiselerin, Allah merkezli dil dizgesi ve Ortaçağ'daki genel idrak seviyesi dâhilindeki anlatımı' olduğudur. Nitekim Ortaçağ insanı, doğal hadiseleri gaybî/metafizik faktörlerle ilişkilendirerek ona abartı ve gizem atfetme itiyadına sahiptir. (Öztürk, 2016: 175) Mucizelerin birer olağanüstü olay olduğu noktasında, Allah Teâlâ bunları yaratmaya elbette kadirdir. Ancak ikinci değerlendirme, kanaatimizce eşyanın tabiatına daha uygun ve o derece de makuldür. Dolayısıyla mucizelerin sebep-sonuç ilişkisi dâhilinde değerlendirilmesi mümkündür. Mucizelerin Kur'ân'da olağanüstü çizgide ele alınmasının sebebi, tarihsel bağlamda insanların o dilden anlaması olsa gerektir.

Kıssa ve mucizelerin bilimsel açıklamasının imkânı konusuna gelirsek, Kur'ân ve sahih sünnette aksine bir yasaklamanın bulunmamasından hareketle, kıssaların ve dolayısıyla mucizelerin sünnetullah ve sebep-sonuç ilişkisi dâhilinde bilimsel birer açılamasının da bulunabileceği kanaatinde olduğumuzu daha önce ifade etmiş idik. Bu konuda yapılan bazı değerlendirmeleri şöyle sıralayabiliriz. 
Şah Veliyyullah Dehlevî̀ye (1704-1762) göre mucizeler, peygamberliğin bir parçası olmamakla birlikte çoğu kez gerekli görülmüştür. (ed-Dehlevî, 2003: 1: 294) Dahası mucizeler tam manasıyla âdet dışı olağanüstü olaylar olmadığı gibi bütünüyle âdete aykırı da değildir. Ancak âdet (sebep-sonuç ilişkisi) formatı, herhangi bir kademede mucizelerle birlikte bulunur. Şah Veliyyullah Dehlevî bu hususta şöyle der:

“Biliniz ki Allah, bir amaca yönelik mucize kabilinden olağanüstü bir olay izhar edeceği zaman, -zayıf bile olsa- onu bir âdet (sebep-sonuç ilişkisi) dâhilinde gerçekleştirir. Mucizeler (الخوارق) zayıf sebepler olarak, hiçbir şekilde âdetin ihlal edilmemesi şartıyla Allah'ın hüküm ve yardımının sebep-sonuç ilişkisi içerisindeki uygulamasının bir işareti olarak meydana getirilmiştir. Kur'ân ve Sünnette buna delâlet eden birçok işâret vardır. Kıssalarda da arif kişilerle, insaflı akıl sahibi herkesin bilmekte olduğu ima ve içerik bulunmaktadır. (ed-Dehlevî, 7)

J. M. S. Baljon (1880-1960), Şah Veliyyullah Dehlevî'nin Hüccetü'l-Bâliğa'da akla yaptığı vurgu ile mucizeleri akılla izah etmesinin temelinde Batı etkisinin önemli bir yer tuttuğunu iddia etmektedir. (Baljon, 1994: 15) Ancak Baljon'ın bu iddiasının isabetli olmadığı, Fazlur Rahman'ın (1919-1988) da ifade ettiği gibi Şah Veliyyullah Dehlevî'nin ilmî faaliyetlerinin modernizm öncesi sslahat hareketleri kapsamında değerlendirilmesi gerektiği kanaatindeyiz. Zira Hindistan'daki ıslahat hareketlerinin başlangıcı 16. yüzyıla kadar uzanmaktadır. Üstelik bu hareketler, Modernizm'in etkisiyle değil, İslâm'ın bizzat kendi bünyesinden zuhur etmiş dinî hareketlerdir. Aksini iddia edip ve böyle bir etkiden bahsetmek tarihsel bir saçmalık olacaktır. Buna mukabil, İslâm Modernizmi, Modernizm öncesi 1slahat hareketlerinin bir devamı konumundadır. (Fazlur Rahman, 2016: 300, 320; 2015: 46, 50) Ayrıca İslâm âlemindeki ıslahat ve modernleşme çalışmaları, dini yorumlama çabasının bir parçasıdır. (Albayrak, 2014: 26)

Şah Veliyyullah Dehlevî'nin değerlendirmesine göre mucizeler de sünnetullah bağlamında bir sebep-sonuç ilişkisi dâhilinde gerçekleşmektedir ve bunların bu çerçevede birer açıklaması vardır. Ayrıca o, Kur'ân'da peygamberleri yalanlayan kavimlerin cezalandırılması ile ilgili cezâî unsurların (helakların), tabiat kanunlarına uygun olarak vâki olduğunun söyler. Zira onun altında yatan gizli maddî/tabiî gerekçeler vardır. (Baljon, 1994: 15) Mucizelerin metafizik birer hadise olarak algılanmasının sebebi, belki de bu güne kadar sırrına vakıf olunamamasından kaynaklanmaktadır.

Muhammed Abduh'un; “mucizelere olan imanımız, yaratılmışlarla ilgili Allah'ın (cc.) sünnetleriyle yol bulmamıza ya da bunların değişmeyeceği ve dönüşmeyeceği şeklindeki itikadımıza engel değildir" ile "Allah'ın yaratılmışlar hakkındaki kanununda/sünnetinde değişim ve dönüşüm olmaz/olamaz" (Reşid Rızâ, 1947: 1: 314-315) sözü kanaatimizce onun da mucizelerin sebep-sonuç ilişkisi dâhilinde makul birer açıklamasının imkânına inandığına delalet etmektedir. Bu bağlamda M. Abduh'un bazı mucizelere yönelik tevillerini (tevil denemelerini) aşağıda zikredeceğiz.

Kur'ân'da, geçmiş peygamberlere atfedilen birçok harikadan/mucizeden söz edildiğinde kuşku yoktur. Kanaatimizce bu hadiseleri değerlendirmede algı ve yorum hataları yapılmaktadır. Çünkü bunların -birçok din bilimcisi tarafından yapıldığı üzere- makul yorum ve açıklamaları vardır. Üstelik hiçbir âlim, sünnetullah dairesinde yaptığı makul izahın mutlak yani 
son söz olduğunu iddia etmemiştir, etmemelidir de. Buna rağmen bağnazlık edilerek söz konusu yorum sahiplerinin; determinist, pozitivist, natüralist, materyalist, oryantalist vb. sıfatlarla yaftalanmaması gerekir. Üstelik bu, ilim ahlakına da yaraşmaz. Birer ictihâd mesabesinde olan bu yorumlar, tartışmaya açık konulardır ve hiçbir kimseye bu yorumları kabul etmesine yönelik herhangi bir dayatma yapılmamaktadır. Bu işin bir yönüdür. İşin diğer yönü, çağdaş tefsir anlayışının temel gayelerinden birinin, 'Kur'ân metnini -o gün bir karşıl1ğı olsa da bu günün insanında bir karşılığı bulunmayan- masalsı/mitolojik unsurlardan arındırmak' olduğu muhakkaktır. Bu maksatla kıssa ve mucizeler çağdaş müfessirler tarafından yeniden yorumlanmaktadır.

Kısaca, gelinen noktada, kıssalarda geçen olağanüstü olaylarla ilgili, Arkeoloji, Antropoloji, Tarih, Coğrafya ve benzeri modern bilimlere ait verileri göz ardı etmemiz mümkün görünmemektedir. Dahası, modern bilimler yardımıyla kıssalar üzerinde yapılacak değerlendirmeler, yeni bir perspektif ile ele alınmalarından mütevellit, kıssalardan eskiye nazaran insanlığın maslahatına yönelik- daha elverişli ilkeler çıkarılmasına imkân verebilecektir.

Son olarak mucizelerin aklen izahına yönelik şu tespitlerde bulunmamız mümkündür:

a- Mucize gelenekte; "muhatap kitle tarafından bir mantık zeminine oturtulamayan (tabiat kanunları bağlamında açıklanamayan) hârikulâde/olağanüstü olayları tesmiye etmek için kullanılan bir kavramdır. Ancak, mucizelerin, gerçekleştiği süreçte -muhatap kitle tarafından- mantıkî bir izahının yapılamamış olması, onların tabiat kanunlarını ihlal eden hadiseler olmasını gerektirmez. Yani her hâriku'l-âde olay hâriku't-tabîa değildir. Gerçekleştiği süreçte hâriku'l-âde görülen bir olay başka bir zamanda ale'-l-âde (olağan) bir olay haline gelebilir. (Zeyveli, 2015: 115-116)

b- Kevnî/hissî mucizelerde görülen olağanüstülük, onların peygamberler eliyle ve tam da onların tabilerinin ya da muarızlarının ihtiyacı ya da meydan okumalarına cevaben gerçekleştirilmesidir. Onların mucize olması muhatap kitlede oluşan bir algıdan ibarettir. Yoksa hadise, tabiat kanunları dâhilinde cereyan etmiştir. Zâlim bir topluluğun, başına deprem, yanardağ patlaması veya bir tusunami felâketi gelmesiyle yok olması bu kabilden bir durumdur. Olaya şahit olanlar bundan, iki olguyu birleştirerek bir helâk çıkarabilirler. Ancak bu husustaki yargı mutlak değildir.

\section{Mucizelerin Bilimsel ve Aklî İzahına Örnekler}

Elmalılı Hamdi Yazır (1878-1942), eş-Şuarâ Sûresi 26/32. âyette söz konu edilen Hz. Musa'nın yılana/ejderhaya dönüşen asâsı (değnek) hakkında şu açıklamayı yapmıştır: Kalb-i hakâik caiz olmaz. Yani gerçek manada bir şeyin başka bir şeye dönüşmesi caiz değildir. Ayrıca: 'Hiçbir şeyi gerçek manada kendisinden uzaklaştırmak (selbetmek) mümkün değildir' anlamına gelen "tenâkuz kanunu" bağlamında bu (asânın ejderhaya dönüşmesi) hakiki bir dönüşüm değildir. Yani asâ hakikaten ejderhaya dönüşmemiştir. Bununla birlikte asânın fiziken ya da manevî olarak zihinde ejderhaya dönüşmesi mümkün olabilir. (Yazır, 1968: 4: 2229-2230) Muhammed Esed (1900-1992), de asâ hakkında; “Asânın mucizevi bir biçimde yılana dönüşmesi kanaatimizce gizemli bir anlam taşımaktadır; bununla öyle anlaşılıyor ki görünüş ile gerçeklik arasındaki mahiyet farklılığına ve buna bağlı olarak Allah'ın bu farklılığ1 kavramak üzere seçilmiş kullarına bahşettiği manevî vukuf ve sezgiye işaret edilmek isteniyor." şeklinde bir açıklama yapmıştır. Devamında en-Neml Sûresi 27/10. ve el-Kasas 
Sûresi 28/31. âyetlerde söz konusu edilen "yılan gibi" benzetmesinden hareketle "asânın bir yılan/ejderha olmadığı, ancak insanların öyle zannettiği" görüşünü savunmuştur. (Esed, 1999: 2: 627)

Diğer bir örnek de Âdem kıssası bağlamında Nisâ Sûresi 4/1. âyet hakkında Muhammed Abduh'un yaptığı açıklamadır. Muhammed Abduh'a göre bu âyetteki "bir tek nefis" ile Hz. Âdem kastedilmemektedir. Çünkü buna nass ve zahir bakımından imkân yoktur. Dahası "Hz. Âdem'in insanlığın atası olduğu” bilgisi bize yakın zamanda İbranîler'den geçmiştir. Çinliler ise tarihi çok daha eskilere varan bir atadan bahsetmektedir. Biz Müslümanların, Yahudilerin tarihini tasdik etmek gibi bir görevimiz bulunmamaktadır. Allah Teâlâ söz konusu âyette insanları kendisinden yarattığ1 "nefs"i nekre yaparak kapalı bırakmıştır. Biz de onu bu haliyle bırakıyoruz. Amacımız, eğer Batılı araştırmacılar bir gün, "insanın her bir sınıfının ayrı bir atası vardır" iddialarını ilmi verilere dayandırarak ispat edecek olurlarsa, bunun Kur'ân ile çelişmediğini ortaya koymaktır. Çünkü Kur'ân, "İnsanlığın atası Âdem'dir" dememektedir. (Reşid Rızâ, 1947: 4: 323-324; Abduh,1993: 5: 160)

Görüldüğü gibi Muhammed Abduh bu kıssayı, mesnetsiz olduğunu düşündügü İsrâiliyât ile değil, nassın zahirine ve dile dayanarak ve ayrıca bilimsel verileri dikkate alarak açıklamıştır. Kanaatimizce bu da onun, Allah'ın kâinata yerleştirdiği âyetlerin, -akıl, deneme-yanılma ve tecrübe yardımıyla- insanoğlu tarafından keşfi neticesinde geliştirdiği bilimlere verdiği değeri göstermektedir.

Kıssa ile bağlantılı diğer bir husus da Âdem ve eşinin konulduğu cennet, bu cennetteki yasak ağaç ve Âdem' in eşiyle birlikte cennetten çıkarılmaları (hübût) meselesidir. Muhammed İkbal'e göre Kur'ân, bu kıssada yer alan bazı kadîm sembolleri, kısmen muhafaza etmekle birlikte, -Kitâb-1 Mukaddes'te (Tekvin babı) tarihsel olarak anlatılanın dışında- ona yeni bir anlam yükleyerek kıssayı bütünüyle maddî olarak dönüştürmüştür. Kur'ân'ın bu kıssayı ele almasındaki amacı tarihsellik değildir. Kıssa bağlamında Kur'ân'da geçen Âdem kelimesi, müşahhas bir bireyin adı olmaktan ziyade bir kavram/ıstılah olarak kullanılmıştır. (İkbâl, 2016: 115-117)

Muhammed İkbal'e göre kıssada Hz. Âdem ile eşinin içine konulduğu zikredilen "cennet", sâlih insanların edebî ikamet yeri anlamina gelen "Cennet" değildir. Zira bu cennet Kur'ân'da; "Onlar orada karşıllılı kadeh alıp verirler, Ancak o içecek ne saçmalamaya yol açar ne de günah işlemeye" (et-Tûr 52: 23) ve "Orada hiçbir yorgunlukla karşılaşmayacaklar. Oradan çıkarılmaları da söz konusu olmayacaktır." (el-Hıcr 15: 48) şeklinde tasvir edilmiştir. Ancak kıssada zikredilen "cennet"te (bahçe) meydana gelen ilk hadise, insanın itaatsizlik günahıdır. Bunu, Âdem ile eşinin o bahçeden çıkarılması takip etmiştir. Dahası bu bahçe, Tâhâ Sûresi 20/118 ve 119. âyetlerde "açlı̆̆ın, susuzluğun, çıplaklı̆̆ın ve sıcaktan bunalmanın söz konusu olmadığı bir yer" olarak tasvir edilmektedir. (İkbâl, 2016: 118) Muhammed İkbal, Kur'ân'ın anlatımındaki "cennet" in, insanın bulunduğu ilkel halin tasavvuru olduğunu düşünme eğilimindedir. Ona göre Kur'ân'daki düşüş kıssasının insanın bu gezegende ortaya çıkışıyla hiçbir ilişkisi yoktur. Bu kıssanın amacı, -daha ziyade- insanın ilkel bir içgüdüsel iştah halinden çıııp, şüphe ve itaatsizliğe yetenekli olan şuurlu bir özgür kimlik/benlik sahibi olmaya yönelik yükselişini açklamaktır. İniş/düşüş (hübût), herhangi bir ahlâkî bozukluk değil, insanın basit şuurdan benlik şuuruna geçmesi (kimlik sahibi olması) şahsiyet kazanarak tabiat uykusundan uyan- 
ması demektir. İnsanın itaatsizliği irade sahibi olmasına ve özgürlüğüne tekabül eder. Allah'ın insanı, iyiliğe de kötülüğe de elverişli yaratması, O'nun insana olan engin inancını göstermektedir. (İkbâl, 2016: 118-119)

Muhammed Hamidullah (1908-2002) Hz. Peygamber'in “Şakku'l-Kamer" mucizesini şöyle izah etmiştir:

“Hz. Peygamber parmağı ile işaret yapar yapmaz Ay ikiye ayrılır. Hadisenin dış görünüşü budur. Bizim açımızdan bakacak olursak bu bir mucizedir. Çünkü normal şartlar altında Ay'ın ikiye yarılmayacağını herkes bilir. Mademki onun (sav) işareti üzerine yarılmıştır, öyleyse bu bir mucizedir. Fakat diğer taraftan bu hadise Allah'ın meş'iyyeti (sünnetullah) muvacehesinde; Ay'ın filan gün filan vakit ve filan yerde yarılması, milyonlarca yıl önce Allah tarafından takdir edilmiş olabilir. Mesela Ay'ın içinde eskiden beri bir çeşit gaz bulunabilir. Bu gazın patlaması neticesinde meydana gelen zelzelede Ay ikiye yarılmış olabilir. Dediğim gibi açık bir sebep gördüğümüz yerde biz, 'bu şey şu sebebin neticesidir' diyoruz. Buna mukabil, Allah için mucizenin sebebi hakkında herhangi bir sual söz konusu olamaz. Çünkü O, sebeplerin müsebbibi ve yaratıcısıdır. Diğer taraftan Ay'ın ikiye yarılışına bizim mucize dememiz bir tek sebepten ileri gelmektedir. $\mathrm{O}$ da; peygamberlerden bir peygamberin inkârcıların karşısında peygamberliğini ispat etme ihtiyacı duyduğu sırada, şu zaman, şu gün veya şu yerde bu hadisenin vuku bulmuş olmasıdır. Fakat bu yarılma hadisesi belki tam o anda vuku bulmayabilirdi de; Ancak Allah'ın yarattığı ve milyonlarca yıldan beri sürüp gelen birbiriyle alakalı sebepler, sebeplerin sebepleri neticesindedir ki, o anda vuku bulmuştur." (Hamidullah, 2015: 144-145)

Muhammed Hamidullah, Bakara Sûresi 2/60. âyette söz konusu edilen “Hz. Musa'nın kayadan su fışkırtması mucizesi" hakkında da şu açıklamayı yapmıştır:

“Hz. Musa asâsı ile bir kayaya vurur vurmaz kayadan on iki göz pınar kaynamaya başladı. Biz buna mucize diyoruz. Niçin? Çünkü Hz. Musa'nın ve yanındakilerin suya ihtiyacı vardı. Normal olarak çölde su bulunması da çok uzak bir ihtimaldi. Hz. Musa kayaya vurunca hemen pınarlar kaynamaya başladı. Bu hadisenin oluş şekli şöyle izah edilebilir: Bildiğiniz gibi pınarlar topraktan veya kayadan çıkar. Toprak altında veya dağların içindeki havuza benzer yerlerde damla damla sular uzun seneler boyunca birikir. Bu görünmeyen kapalı havuzun zayıf bir noktasından, bir menfezden sular dışarı çıkabilir. Biz de buna pınar deriz. Bir havuzun bir duvarı zayıf diğer duvarları daha sağlam olabilir ve şayet biz bu zayıf tarafa bir asâ ile vuracak olsak buradan bir pınar kaynayabilir. Aynı şekilde Cenâb-1 Hak binlerce yıl önceden, 'filan tarih, filan gün, filan vakit ve filan yerde Peygamber Musa bulunacak, suya ihtiyacı olacak, filan kayanın şu ince tarafına asâsı ile vuracak ve buradan pınarlar kaynayacak' şeklinde takdir etmiş, bunun sebepleri de Allah'ın takdirine göre binlerce seneden beri tekâmül edip o anda tahakkuk etmiş olabilir. Meselâ bugün ben Erzurum civarında bir dağa gitsem ve orada rasgele vurduğum bir yerden su çıkmaya başlasa, siz buna mucize demeyeceksinizdir. Hâlbuki peygamberlerden biri, çölde suya ihtiyacı olduğu bir anda, aynı şeyi yapmış olsa, işte biz buna mucize diyoruz." (Hamidullah, 2015: 145-146) 
Görüldügü gibi Muhammed Hamidullah, mucizeleri, sünnetullah ve sebep-sonuç ilişkisi dâhilinde açıklama gayretindedir ve kanaatimizce yaptığı aklî izahatın dine aykırı bir yönü bulunmamaktadır. Mucizelerin, o günün muhataplarına bu şekilde aklî izahının yapılmaması, ya mucizelerin bu gizemli anlatım ile daha etkili hale getirilmesinin amaçlanmasından, ya onların geleneğinde soyut anlatımın bulunup, somutlaştırmanın bulunmamasından, ya da onların bu tür bir izahı anlayacak durumda olmamalarından kaynaklanmaktadır.

el-Bakara Sûresi 2/63 ile el-A'râf Sûresi 7/171. âyetlerde söz konusu edilen "Allah'ın Sina dağını İsrâiloğulları'nın üzerine kaldırılması" kıssası hakkında Süleyman Ateş şu değerlendirmeyi yapmıştır:

“Burada Allah'ın Sina dağını, İsrâiloğulları'nın üstlerine kaldırdığı, A'râf Sûresi'nde ise 'dağın bir gölge gibi üstlerine kaldırıldığı, onların da dağın üstlerine düşeceğini sandıkları' anlatılmaktadır. Allah dilerse bir mucize olarak dağı insanların üstüne kaldırır. Ama Kur'ân-1 Kerîm'de "Allah'ın yasasında bir değişiklik bulamazsın" (el-Ahzâb 33: 62; Fâtır 35: 43; el-Feth 48: 23) buyurulduğu üzere Allah, genel yasasını değiştirmez. Dağı da genel yasası uyarınca bir deprem olayıyla İsrâiloğulları'nın üstüne kaldırır. Dağın eteğinde bulunan insanlar dağın üstlerine düşeceğini sanırlar ve bunun kendi hata ve günahları yüzünden ileri geldiğini anlayarak Allah'a tövbe edip O'ndan mağfiret dilerler. Nitekim bazı bölgelerde dağların kaydığı, eteğindeki evlerin yıkıldığı, insanların paniğe kapıldığı bilinen olaylardandır. Genellikle halk böyle durumlarda Allah'a yönelir, hata ve günahlarından tövbe ederler. İşte kıssada İsrâiloğulları'nın başına gelmiş böyle bir olay anlatılmaktadır." (Ateş, 1989: 1: 177)

Yoksa âyetin zahiri anlamıyla dağ, kökünden sökülüp kaldırılıp tepelerinde tutulmuş ve asılı bırakılmış değildir. Zira dağlık bölgelerde dolaşan insanlar, bazen büyük kaya parçalarının çıkıntı halinde yerlerinden oynayıp, tabiri caizse bir kubbe gibi durduklarını ve aşağıda bulunan insanlarda başlarına düşecekmiş izlenimini uyandırdıklarını çok iyi bilirler. (Baljon, 1994: 37)

Mucizelerin bilimsel açıklamasının imkânına ve bu çerçevede anlaşılmasına yönelik daha birçok örnek bulunmasına rağmen konunun bir makale boyutunu aşmaması adına verdiğimiz örneklerle yetinmek istiyoruz.

\section{Sonuç}

Kur'ân'da, geçmiş toplumlara ve peygamberlere ait bir takım kıssaların bulunması onun i'câz yönlerinden biridir. Allah Teâlâ söz konusu kıssalardan bahsetmekle, geçmişin tecrübesinden yararlanmamızı hedeflediği kadar, taşıdıkları küllî, ahlâkî ve felsefî manalar yardımiyla yeryüzünde birer halife olarak -tevhîd akidesi ekseninde- faziletli bir toplum oluşturma çabalarımıza katkı sağlamayı hedeflenmiştir. Kur'ân kıssalarında kişi ve yer isimlerinden bahsedilmemiş olması kıssaları evrenselleştirmeye yönelik olsa gerektir.

Kıssaların tarihsel (edebî), dramatik (temsilî) ve mitolojik (ustûrî) olmak üzere üçe taksim edilmesi, çağımızda kıssa ve mucizeler etrafında oluşan problemlerin çözümünde sadra şifa bir yöntemdir. Nitekim bu, öteden beri bazı müfessirler nezdinde caiz görülmüştür. Bu anlamda Allah'ın meramını, muhataplarının anladığı dilden konuşmak suretiyle temsîlî ve mitolojik unsurlarla anlatması onun adına bir noksanlık değildir. 
Tüm olayları, pozitivist bir yaklaşımla sebep-sonuç ve nedensellik prensibi ekseninde değerlendirme eğiliminde olan modern insana -anladığ 1 dilden hitap ederek- cevap verebilmek adına Kur'ân kıssalarının modern bilimler ışığında da açıklanması önemli bir konudur.

Modern bilim, bir nevi Allah'tan bağımsız ve fakat onun kurduğu nizam içerisinde kâinatı akıl yardımıyla anlamlandırmayı esas alan, kâinatın emri ve tasarrufunda insanın özne olduğu bilim anlayışını karşılayan bir kavramdır. Bu anlayışa göre varlık, -"gizemsiz, büyüsüz ve mucizesiz bir dünya" fikri ekseninde- doğrudan doğruya Tanrı'nın kendisine müdahale ettiği bir nesne değil, bunun yerine fizik ve matematiğe ait kurallar bağlaminda yorumlanan bir nesnedir.

Kur'ân kıssalarıyla ilgili en önemli meselelerden biri, kıssalarda yer alan ve çoğu peygamberlere ait olan harikaların/hissî mucizelerin modern bilimlere ait yöntemlerle, yani, sebepsonuç, nedensellik, yalınlık, ölçülebilirlik, tarafsızlık ve tarihi kronolojiye uygunluk gibi ölçütlerle değerlendirilmesi meselesidir. Bu hususta Müslümanlar arasında bir ittifak söz konusu olmamıştır. Genel eğilim, kıssaların bilimsel ölçütlerle değerlendirilemeyeceği yönünde olmasına rağmen, Kur'ân ve sahih sünnette buna yönelik bir yasaklamanın bulunmamasından hareketle, Kur'ân kıssalarında yer alan birtakım olağanüstülüklerin -sünnetullah ve sebep-sonuç ilişkisi dâhilinde- bilimsel birer açıklamasının da bulunması muhtemeldir. Nitekim bazı kıssalarda söz konusu edilen olağanüstü hadiseler (mucizeler), bazı müfessir ve düşünür tarafından modern bilimlere uygun olarak -sebep-sonuç ve illiyet prensibi çerçevesinde- açılanmaya çalışılmıştır. Dahası, er-Rûm Sûresi 30/41 ve daha birçok âyet sebebe ve nedenselliğe vurgu yapmaktadır. Bunları görmezden gelmek mümkün değildir.

Mucizeler, nübüvvet iddiasında bulunan kişileri desteklemek amacıyla onlar eliyle gerçekleşen ve benzerinin diğer hiçbir kimse eliyle gerçekleştirilmesinin mümkün olmadığ failinin Allah (cc) olduğu olağanüstülüklerdir. "Bizim Peygamberi mucizelerle göndermemize mâni olan şey, ancak o mucizeleri öncekilerin yalanlamış olmasıdır..." [İsrâ, 17/59] âyeti hissi/kevnî mucizeler devrinin çoktan kapandığının açık bir delilidir. Kur'ân'a göre Hz. Peygamber'e mucize göstermesine yönelik defalarca meydan okunduğu halde müşriklerin bu taleplerine Allah (cc) tarafından hiçbir surette olumlu cevap verilmemiştir. Kur'ân'da, Hz. Musa, Hz. İsâ ve diğer önceki peygamberler eliyle gerçekleşen bir takım kevnî hârikalardan bahsedildiği halde Hz. Peygamber'e meydan okumalara karşı verilen herhangi bir harikadan/kevnî mucizeden bahsedilmemektedir. Yukarıdaki âyetle birlikte bu da Hz. Peygamber'e hissî mucize verilmediğine delalet eder. Kur'ân'da hissî mucizelere yönelik hiçbir işaret ve ima bulunmamasına rağmen Hz. Peygamber'e çok sayıda hissî mucize atfedilmesi oldukça düşündürücüdür. Kanaatimizce onun en büyük mucizesi Kur'ân'dır.

Kıssalarda söz konusu edilen hârikaların/mucizelerin tabiatı hakkında iki değerlendirme söz konusudur. Bunlardan ilki, 'onların âdetullah dışı olağanüstü olaylar' olduğu; diğeri de 'olağan hadiselerin, Allah merkezli dil dizgesi ve Orta çağdaki genel idrak seviyesi dâhilindeki anlatımı' olduğudur. Kanaatimizce ikinci değerlendirme daha isabetli görünmektedir.

Kıssa ve mucizelerin, sünnetullah ve sebep-sonuç ilişkisi dâhilinde bilimsel ölçütler ile açılanması mümkündür. Kur'ân ve sahih sünnette aksine bir yasaklama bulunmamaktadır. Bu konuda, Şah Veliyyullah Dehlevî vb. bazı âlimler tarafından yapılan "mucize suretinde olan harikaların bazılarının, aslında beşerî imkândan hariç bulunmadığı; onların tam manasıyla âdet dışı olağanüstü olaylar olmadığı gibi bütünüyle âdete aykırı da dolmadığı. Ancak âdet 
(sebep-sonuç ilişkisi) formatı, herhangi bir kademede mucizelerle birlikte bulunduğu" şeklindeki değerlendirmeler yerindedir. Yani mucizeler, sünnetullah bağlamında sebep-sonuç ilişkisi dâhilinde gerçekleşmektedir ve her birinin bu çerçevede makul bir açıklaması vardır.

Kur'ân'da, geçmiş peygamberlere atfedilen harikaları/mucizeleri değerlendirmede algı ve yorum hataları yapılmaktadır. Çünkü bunların âdetullah/sünnetullah çerçevesinde makul yorum ve açıklamaları vardır. Birçok din bilimcisi de bu tür hadiselere bu çerçevede makul izahlar getirmiş ve getirmeye devam etmektedir. Burada önemli olan, getirilen yorumun mutlak yani son söz olduğunu iddia etmemektir. Durum böyle iken bağnazlık edilerek söz konusu yorum sahiplerinin; determinist, pozitivist, natüralist, materyalist, oryantalist vb. sıfatlarla yaftalanmaması gerekir. Üstelik bu, ilim ahlakına da yaraşmaz. Harikalara/mucizelere getirilen makul yorumlar birer içtihattır ve dolayısıyla tartışmaya açık konulardır. Hiçbir kimseye bu yorumları kabul etmesine yönelik herhangi bir dayatma yapılmamaktadir.

İki örnek ile sözümüzü noktalamak istiyoruz. İlki; Şuarâ Sûresi 26/32. âyette söz konusu edilen Hz. Musa'nın ejderhaya dönüşen asâsı, Elmalılı Hamdi Yazır'ın da ifade ettiği gibi, hakikaten ejderhaya dönüşmüş değildir. Bu, olsa olsa fiziken ya da manevî olarak zihinde gerçekleşen bir dönüşümdür. İkincisi; Âdem kıssasında söz konusu edilen Âdem ve eşinin içine konulduğu cennet, Muhammed İkbal'in de dediği gibi sâlih insanların ebedî ikamet yeri anlamına gelen "cennet" değildir. Kissada zikredilen cennette meydana gelen ilk hadise de insanın itaatsizlik günahıdır. Kur'ân'daki düşüş kıssasının, insanın dünyada ortaya çıkışıyla hiçbir ilgisi yoktur. الله أعلم 


\section{Kaynakça}

Abduh, M. (1993). el-A'mâlü'l-Kâmile. Thk: M. Amâra. Beyrut: Dâru'ş-Şurûk.

Abdülkâhir el-Bağdâdî, Ebû Mansûr Abdülkâhir b. Tahir b. Muhammed. (ts.) el-Fark beyne'lFırak ve Beyânü'l-Firkati'n-Nâciye. Thk. M. Osman el-Haşin. Kahire: Mektebetü İbn Sina.

Albayrak, İ. (2014). Klasik Modernizmde Kur'ân'a Yaklaşımlar. İstanbul: Ensar Neşriyat.

Ateş, S. (1989) Yüce Kur'ân'ın Çă̆daş Tefsiri. 12 Cilt. İstanbul: Yeni Ufuklar Neşriyat.

Bağçeci, M. (2000). “Sünnetullah” Şamil İslâm Ansiklopedisi. (7: 257-258). 8 Cilt. İstanbul: Şamil Yayınevi.

Baljon, J. M. S. (1994). Kur'ân Yorumunda Çă̆daş Yönelimler. Trc. Şaban Ali Düzgün. Ankara: Fecr Yayınları.

Buhârî, Ebû Abdillah Muhammed b. İsmail. (1992). el-Camiu's-Sahih. 2. Baskı. Nşr. Muhammed Fuat Abdülbaki. İstanbul: Dâru Sahnûn ve Çağrı Yayınları.

Câvîş, Abdülaziz. (1968). el-İslâm Dînü'l-Fıtrati ve'l-Hurriyye. Mısır: Dâru'l-Meârif.

Çağırıcı, M. - Karaman, H. - Dönmez, İ. K. - Gümüş, S. (2006). Kur'an Yolu Türkçe Meal ve Tefsir. 5 Cilt. Ankara: Diyanet İşleri Başkanlığ

Çetin, A. (2012). Kur'ân İlimleri ve Kur'ân-ı Kerim Tarihi. İstanbul: Dergâh Yayınları.

Dehlevî, Şah Veliyyullah. (ts.). Te'vîlü'l-Ehâdîs. Delhi: Matbau Ahmedî.

Dehlevî, Şah Veliyyullah. (2003). Hüccetü'l-Bâliğa, Trc. Mehmet Erdoğan. Ankara: Yeni Şafak Yayınları.

Demir, Ş. (ts.). Mitoloji, Kur'ân Kıssaları ve Tarihi Gerçeklik 3. Baskı. İstanbul: Beyan Yayınları.

Demircan, A. (2015) “İslâm Tarihinin İlk Üç Asrında Mucize Algısı Üzerine Bazı Değerlendirmeler". Din Dilinde Mucize. (s. 179-212). İstanbul: Kur'ân Araştırmaları Merkezi (Kuramer) Yayınları.

Draz, M. A. (2016). Kur'ân'a Giriş. 6. Baskı. Çev. Salih Akdemir. Ankara: Otto Yayınlar.

Doğan, D. M. (1996). Büyük Türkçe Sözlük. İstanbul: İz Yayıncılık, 1996.

Ersöz, R. (2018). Selefilik ve Selefî Tefsir Anlayışı. İstanbul: Ensar Neşriyât.

Ersöz, R. (2019). Yol Ayrımındaki Selefîlik: Klasik İslâm Modernizmi'nin Kur'ân Alg̨sı. İstanbul: Ensar Neşriyât.

Esed, M. (1999). Kur'ân Mesajı/Meal - Tefsir. 3 Cilt. Çev. C. Koytak - A. Ertürk. İstanbul: İşaret Yayınları.

Fahd b. Abdurrahman b. Süleyman er-Rûmî. (1983). Menhecü'l-Medreseti'l-Akliyyeti'l-Hadîse fi't-Tefsîr 2 Cilt. Riyad: Müessesetü'r-Risâle.

Fahreddîn er-Râzî, Ebû Abdillah Muhammed b. Ömer. (2013) Mefâtihu'l-Ğayb 33 Cilt. 4. Bask1. Beyrut: Dâru'1-Kütübi'l-İlmiyye. 
Fayda, M. (2000 ). “İfk Hadisesi”. Türkiye Diyânet Vakfı İslâm Ansiklopedisi. (21: 507-509). 44 Cilt. İstanbul: T.D.V. Yayınları.

Fazlur Rahman. (2016). İslâm, Trc. M. Dağ - M. Aydın. Ankara: Ankara Okulu Yayınları.

Fazlur Rahman. (2015). İslâmî Yenilenme Makaleler III. Trc. A. Çiftçi. Ankara: Ankara Okulu Yayınları.

Fîrûzâbâdî, Ebu't-Tâhir Mecdüddîn Muhammed b. Ya'kub b. Muhammed. (1996). Besâir Zevi't-Temyîz fì Latâifi'l-Kitabi'l-Azîz. 6 Cilt. 3. Baskı. Kahire.

Halefullah, Muhammed Ahmed. (2002). Kur'ân'da Anlatım Sanatı el-Fennü'l-Kasasî. Trc. Şaban Karataş. Ankara: Ankara Okulu Yayınları.

Hamidullah, M. (2015). Sorunlar, Sorular ve Cevaplar. Trc. Z. Aksu. Haz. K. Yeşil. İstanbul: Beyan Yayınları.

Hasan Ziyâuddîn Itr. (1994). el-Mu'cizetü'l-Halide. Beyrut: Dâru'l-Beşâiri'l-İslâmiyye.

İbn Âsûr, Muhammed Tahir. (1984). et-Tenvîr ve't-Tahrîr. 30 Cilt. Tunus: ed-Dâru't-Tûnisiyye.

İbn Hacer el-Askalânî, Ebu'l-Fadl Şehabeddîn Ahmed. (ts.). Fethu'l-Bârî bi Şerhi Sahîhi'lBuhârî. 13 Cilt. Thk. M. Fuad Abdülbâkî-M. el-Hatîb. Kahire: el-Mektebetü's-Selefiyye.

İbn Kesîr, Ebu'l-Fidâ İsmail. (1985). Tefsîru'l-Kur'âni'l-Azîm. 8 Cilt. Thk: M. İbrahim el-Bennâ - M. Ahmed Aşûr - A. Ğanîm. İstanbul: Kahraman Yayınları.

İbn Manzûr, Cemâleddin Muhammed b. Mükrim. (ts.). Lisânü'l-Arab. 15 Cilt. Beyrut: Dâru Sâdır.

İbn Rüşd, Ebu'l-Velîd Muhammed. (1964). Tehafütü't-Tehafüt. Thk. Dr. S. Dünya. Kahire: Dâru'lMeârif.

İbn Teymiye, Takıyyüddin Ahmed b. Abdilhalim. (2004). Mecmûu Fetâvâ. 37 Cilt. Cem ve Tertib: Abdurrahman b. Muhammed b. Kasım ve Oğlu. Medine.

İbn Useymîn, Muhammed Sâlih. (2001). Usûlün fítt-Tefsîr. Kahire: el-Mektebetü'l-İslâmiyye.

İbrahim Mustafa - Ahmed Hasan ez-Ziyât - Hamid Abdülkâdir - Muhammed Ali en-Neccâr. (1989). el-Mu'cemu'l-Vasît. 2 Cilt. “a-c-z" maddesi. (2: 585). İstanbul: Çağrı Yayınları.

İkbâl, M. (2016). İslâm'da Din̂̂ Düşüncenin Yeniden İnşâsı. Trc. R. Acar. İstanbul: Timaş Yayınları.

Kitâb-1 Mukaddes. (1997). İstanbul: Kitâb-1 Mukaddes Şirketi.

Kurtubî, Ebû Abdullah Muhammed b. Ahmed. (2006). el-Câmi li Ahkâmi'l-Kur'ân. 24 Cilt. Thk. Abdullah b. Abdilmuhsin et-Türkî. Beyrut: Müessesetü'r-Risale.

Kutub, S. (1969). Kur'ân-ı Kerim'de Edebî Tasvir. Çev. S. Ateş. Ankara: Hilal Yayınları.

Nesefî, Ömer b. Muhammed Ebû Hafs. (2007). İslâm İnancının Temelleri Akâid. Trc. S. Ahsen. İstanbul: Bayrak Yayıncilık.

Özsoy, Ö. (2017). Sünnetullah: Bir Kur'ân İfadesinin Kavramlaşması. 4. Baskı. Ankara: Fecr Yayınları. Öztürk, M. (2016). Kur'ân Kıssalarının Mahiyeti. İstanbul: Kuramer Yayınları.

Paret, R. (1018). Kur'ân Üzerine Makaleler Der. \& Trc. Ö. Özsoy. Ankara: Otto Yayınları. 
Râgib el-İsfahânî. (ts). el-Müfredât fî Garîbü'l-Kur'ân. Thk: M. Seyyid Keylânî. Beyrut: Dâru'lMa'rife.

Reşid Rizâ, M. (1947). Tefsîru'l-Kur'âni'l-Hakîm/Tefsîru'l-Menâr. Kahire: Dâru'l-Menâr.

Sâvî, Ahmed. (ts). Haşiyetü'l-Allame es-Sâvî alâ Tefsîri'l-Celâleyn. 4 Cilt. Beyrut: Dâru İhyâi'tTürâsi'l-Arabî.

Sefarînî, Muhammed b. Ahmed. (1982). Levâmiu'l-Envâr el-Behiyye ve Sevâtıu'l-Esrâri'l-Eseriyye. Şam: Müessesetü'l-Hafetîn.

Şengül, İ. (2019). Kur'ân Kıssalarının Tarihi Değeri. Ankara: Otto Yayınları.

Vehbe ez-Zuhaylî. (ts). et-Tefsîru'l-Vecîz. Şam: Dâru'l-Fikr.

Yaşar, N. (2017). Oryantalistlere göre Kur'ân'ın Kaynă̆ı ve Metinleşmesi. Ankara: Ankara Okulu Yayınları.

Yavuz, Y. Ş. - Çetin, A. (1991). “Âyet". Türkiye Diyânet Vakfı İslâm Ansiklopedisi. (4: 242-244). 44 Cilt. İstanbul: T.D.V. Yayınları.

Yazır, E. M. H. (1968). Hak Dini Kur'ân Dili. 9 Cilt. İstanbul: Nebioğlu Basımevi.

Zemahşerî, Ebu'l-Kasım Cârullah Mahmud b. Ömer. (2015). el-Keşşâf an Hakâiki Ğavâmizi't-Tenzîl ve Uyûni'l-Ekâvîl fî Vucûhit-Te'vîl. 4 Cilt. Beyrut: Dâru'l-Kütübi'l-İlmiyye.

Zeyveli, H. (2015). "Kur'ân ve Kur'ân Dışı İslâmî Rivâyetlerde Mucize". Din Dilinde Mucize (s. 105-132). İstanbul: Kuramer Yayınları. 